\title{
Working
}

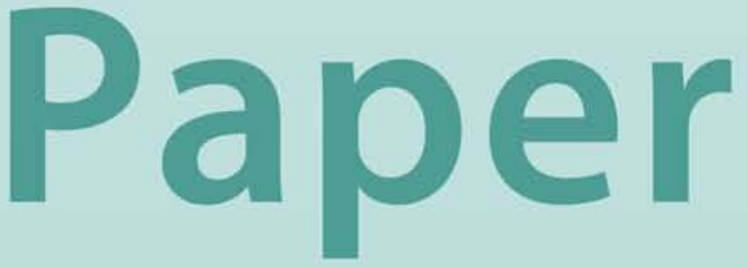


Macroeconomic Costs of Higher Bank Capital and Liquidity Requirements

Scott Roger and Jan Vlček 


\title{
IMF Working Paper
}

Monetary and Capital Markets

\section{Macroeconomic Costs of Higher Bank Capital and Liquidity Requirements}

\author{
Prepared by Scott Roger and Jan Vlček
}

Authorized for distribution by Karl Habermeier

May 2011

\begin{abstract}
This paper uses a DSGE m odel with banks and fi nancial frictions in credit markets to assess the medium-term macroeconom ic cos ts of increasi ng capital and liquidity requirem ents. The analysis indicates that the macroeconomic costs of such m easures are sensitive to the leng th of the implementation period as well as to the ad justment strategy used by banks, and the scope for monetary policy to respond to the regulatory changes.
\end{abstract}

\section{This Working Paper should not be reported as representing the views of the IMF.}

The views expressed in this Working Paper are those of the author(s) and do not necessarily represent those of the IMF or IMF policy. Working Papers describe research in progress by the author(s) and are published to elicit comments and to further debate.

JEL Classification Numbers: E32, E43, E44, G1, G21

Keywords: Capital and liquidity requirements, financial frictions, macro-financial linkages.

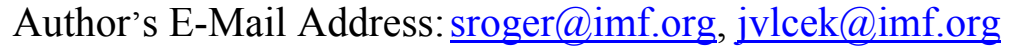




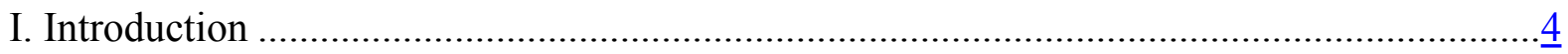

II. Modeling Macro-Financial Linkages ……………........................................................

A. Incorporating a Banking Sector into the Macroeconomic Model.............................. $\frac{5}{6}$

B. Real-Financial Linkages and the Transmission Mechanism...................................... $\frac{6}{6}$

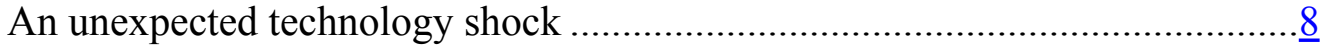

III. Macroeconomic Costs of Increasing Capital and Liquidity Requirements .......................... $\underline{9}$

A. Regulatory Changes and Assumptions ………………........................................

B. Potential Bank R

esponses to an Increase in Capital Requirements ....................................................10

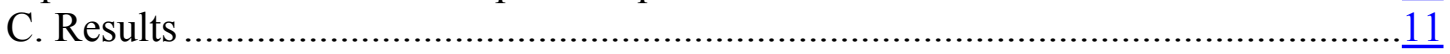

D. An Increase in Liquidity Requirements ........................................................15

E. Sensitivity and Robustness Analysis ................................................................

IV. Concluding Comments and Future Directions ………....................................................

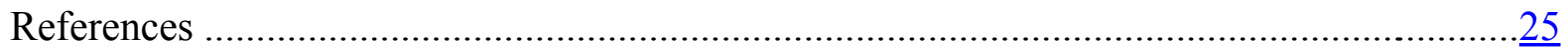

Tables

1. A Representative Bank Balance Sheet...........................................................................

2. The Euro Area - Effects of Tighter Capital Requirements..............................................

3. The United States - Effects of Tighter Capital Requirements............................................13

4. The Euro Area - Effects of Tighter Liquidity Requirements .............................................

5. The United States - Effects of Tighter Liquidity Requirements .......................................

6. The Euro Area - Effects of Tighter Capital Requirements over Different Horizons ...........19

7. The United States-Effects of Tighter Capital Requirements over Different Horizons ......19

8. Effects of Tighter Liquidity Requirements over Different Horizons....................................

9. The Euro Area-Effects of Tighter Capital Requirements under Alternative

Monetary Policy .............................................................................................................

10. The United States-Effects of Tighter Capital Requirements under Alternative

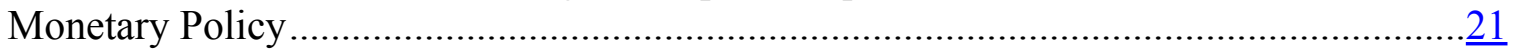

11. Effects of Tighter Liquidity Requirements under Alternative Monetary Policy ................22

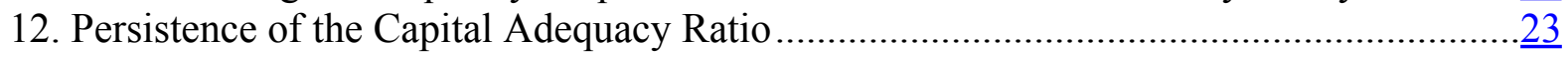

13. Calibration of Model's Parameters Affecting Steady-state ………….............................. 40

14. Implied Model Ratios ................................................................................................

15. Calibration of Model Dynamic Parameters …………………………............................... 42

Figures

1. A Technology Shock....................................................................................................

2. The Euro Area - Increasing Retained Earning via Dividend Policy ………….................... 42

3. The United States - Increasing Retained Earning via Dividend Policy ……....................... 43

4. The Euro Area-Adjusting Banks Assets via the LTV Ratio ..........................................43

5. The United States-Adjusting Banks Assets via the LTV Ratio .........................................44

6. The Euro Area-Adjusting Banks Assets via the LTV Ratio and Portfolio Riskiness ........44

7. The United States-Adjusting Banks Assets via the LTV Ratio and Portfolio Riskiness ...45 
8. Effects of Tighter Liquidity Requirements .............

9. The Euro Area-Effects of Tighter Liquidity Requirements under Different Risk-weighting Assumptions ...................................................................................... 46

10. The United States — Effects of Tighter Liquidity Requirements under Different Risk-weighting Assumptions ........................................................................... 46

11. The Euro Area-Effects of Tighter Capital Requirements over Different Horizons ........ 47

12. The United States - Effects of Tighter Capital Requirements over

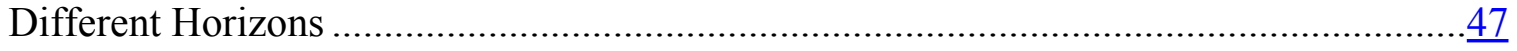

13. The Euro Area-Effects of Tighter Liquidity Requirements over Different Horizons

14. The United States_-Effects of Tighter Liquidity Requirements over

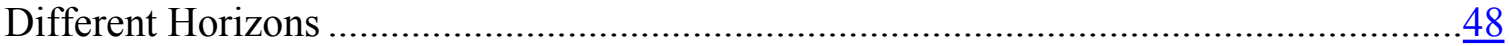

15. The Euro Area-Effects of Tighter Capital Requirements under Alternative Monetary Policy

16. The United States - Effects of Tighter Capital Requirements under Alternative Monetary Policy

17. The Euro Area-Adjustment of the Capital Adequacy Ratio to 1 p.p. Increase of Requirements

18. The United States - Adjustment of Capital Adequacy Ratio to 1 p.p. Increase of Requirements

19. The Euro Area-Effects of the Penalty Parameter ............................................................51

20. The United States -Effects of the Penalty Parameter ...................................................51

Appendix

I. A Description of the Model and Calibration 


\section{INTRODUCTION}

The paper examines the transitional macroeconomic effects of introducing higher capital and liquidity requirements. The analysis uses a Dynamic Stochastic General Equilibrium (DSGE) model including financial frictions and a banking sector. This type of model provides consistency of stock and flow variables, facilitates assessment of the interaction between real and financial sector variables, and allows alternative bank responses to be considered within a consistent framework. The model was calibrated in two versions, with one based on data and parameters for the Euro Area (EA), and the other based on the United States.

The analysis in this paper contributed to the work of the Macroeconomic Assessment Group (MAG), chaired by the Bank for International Settlements (BIS), and the Long-term Economic Impact (LEI) group of Basel Committee for Banking Stability (BCBS). ${ }^{1}$ The MAG participants, including the IMF, used a variety of models to estimate the medium-term macroeconomic costs of strengthening capital and liquidity requirements. The results of these analyses were then collated by the MAG to arrive at a probable range for the effects of the regulatory measures. The analysis presented in the paper, reflecting the MAG mandate, focuses solely on the short-term to medium-term output costs of the proposed new regulatory measures. Estimates of net benefits of the regulatory measures can be found in the LEI report (BCBS (2010)).

The results obtained with the DSGE model presented below are generally in line with the results obtained by other MAG participants using other models, but underscore the importance of some key assumptions. The results suggest that the macroeconomic costs of raising capital and liquidity requirements are likely to be quite moderate, particularly if phased in over an extended period. Implementing tighter capital requirements over a fairly lengthy period not only stretches out the adjustment over time, but also facilitates bank adjustment strategies based on increasing capital rather than cutting lending, which has much higher macroeconomic costs. A longer implementation schedule also makes it more likely that monetary policy can significantly mitigate the macroeconomic effects of the regulatory measures. Capital requirements and liquidity requirements are found to be complementary in the sense that raising bank liquidity will also help to raise capital adequacy.

The paper is organized as follows. In Section II, we describe how a banking sector is incorporated into the model, the financial frictions modifying the macroeconomic transmission mechanism, and the regulatory requirements constraining bank behavior. Section III then discusses the macroeconomic effects of changing capital requirements using alternative bank adjustment strategies, as well as the effects of changing liquidity requirements and their interaction with capital requirements. The section concludes with a discussion of simulations carried out to check the robustness of the results. Section IV provides concluding comments and

\footnotetext{
${ }^{1}$ See MAG (2010a), MAG (2010b), and BCBS (2010).
} 
identifies potential areas for modifying the modeling framework to be able to address additional issues.

\section{Modeling Macro-Financial LinKageS}

\section{A. Incorporating a Banking Sector into the Macroeconomic Model}

The model used in this exercise is a DSGE model including a banking sector and financial frictions in credit markets, and closely resembles the setup developed in Gerali et al. (2010). The explicit representation of bank balance sheets including a variety of financial assets and bank capital facilitates the examination of changes in capital and liquidity requirements. Credit market frictions are introduced using a collateral constraints framework in which the balance sheet positions of households and businesses constrain their access to bank intermediated credit. ${ }^{2}$ Besides financial frictions, the model exhibits a standard array of nominal and real frictions, such as habit persistence and price stickiness. The model is calibrated in two versions to represent the United States and EA economies.

Banks provide financial intermediation services, taking deposits from some households and lending to other households as well as to nonfinancial firms. Lending to the private sector includes household consumer and mortgage loans, as well as loans to entrepreneurs to finance production and capital investment. Households need to secure or collateralize their borrowing with durable assets - housing; while borrowing by non-financial firms is secured against their physical capital assets. The maturity structure of deposits and loans is exogenous and calibrated to reflect the observed degree of flexibility in retail interest rates in the United States and EA.

In addition to loans to the private sector, banks hold highly liquid, risk-free government securities in order to meet liquidity requirements.

On the liability side, banks hold deposits of households and the equity capital of bank shareholders. Banks are required to meet minimum capital requirements defined in terms of the ratio of common equity to risk-weighted assets. The representative bank balance sheet is shown in Table 1.

\footnotetext{
${ }^{2}$ See, e.g., Iacoviello (2005) or Kocherlakota (2000).
} 


\section{Table 1. A Representative Bank Balance Sheet}

\begin{tabular}{|c|c|}
\hline Assets & Liabilities \\
\hline $\begin{array}{l}\text { Loans to households and } \\
\text { firms }\end{array}$ & $\begin{array}{l}\text { Deposits from } \\
\text { households }\end{array}$ \\
\hline $\begin{array}{l}\text { Liquid assets_government } \\
\text { securities }\end{array}$ & $\begin{array}{c}\text { Shareholder equity- } \\
\text { bank capital }\end{array}$ \\
\hline
\end{tabular}

Banks are monopolistic competitors, exercising some control over the spread of their marginal lending and deposit rates with respect to the central bank policy rate. ${ }^{3}$ The spread between deposit and lending rates allow banks to make profits, part of which is distributed to shareholder households according to a fixed dividend payout ratio, with the remaining profits used to cover bank operating costs and to accumulate bank capital reserves. Banks maximize profits by adjusting lending margins over their cost of funds.

The liquidity requirements are described as a mandatory constraint for banks to hold a share of their assets in highly liquid government securities. As these securities provide a lower interest rate margin than loans to the private sector, banks hold the minimum needed to meet the requirement. Liquid securities are issued by government to finance its spending and are characterized by infinite supply, so that banks are able to adjust their holding of government securities at any time without affecting their price.

\section{B. Real-Financial Linkages and the Transmission Mechanism}

The most important aspect of incorporating a financial sector into DSGE models is the introduction of financial "frictions" constraining the intermediation process. For the most part, such frictions arise from informational asymmetries between borrowers and lenders, as well as from transactions costs associated with intermediation or from regulatory constraints. Without such frictions, the addition of an explicit financial sector would have little effect on macroeconomic behavior other than to add an accounting framework corresponding to real activity. In the model used in this analysis, financial frictions are primarily introduced through a collateral constraint framework reflecting information asymmetries between borrowershouseholds and businesses - and lending banks. Additional frictions stem from regulatory measures and assumptions regarding bank behavior.

Along with collateral constraints two structural characteristics of lending may be noted. Although these may not have significant effects on major macroeconomic variables, they do

\footnotetext{
${ }^{3}$ Banks' ability to control spreads are also limited by the maturity structure of loans and deposits, so that changes in rates at the margin take time to feed through into average rates. In the model there are different speeds of adjustment in household and business lending rates and in deposit rates, with household lending rates being slowest to adjust. The speeds of adjustment are set exogenously.
} 
have but significant implications for variables as such as banks profits and household consumption. These features enhance the consistency of model impulses with empirical data and provide a more reliable macro story:

- Debt contracts are assumed be set in nominal terms. This implies that inflation above the expected rate reduces borrowers' real interest rate payments to lenders, while inflation that is lower than expected raises real debt payments, transferring resources from borrowers to lenders.

- $\quad$ The length of time over which interest rates in lending contracts are fixed also shapes the strength and length of the transmission mechanism. The length of lending contracts affects the average spread between lending and policy rates, and also drives profitability of banks. In an economy with a predominance of fixed rate loans with relatively long duration, average retail interest rates will respond sluggishly to changes in policy rates, attenuating their macroeconomic impact in the short term. However, this feature may also lead to a pore persistent impact of interest rate movements, as banks need to adjust interest rate margins over an extended period to compensate for the losses (or gains) associated with policy rate changes.

Regulatory requirements with respect to capital and liquidity impose constraints on the behavior of banks and constitute the third main element shaping the transmission mechanism. To represent the pressure on banks to meet capital requirements, but with some ability to tolerate relatively small deviations from the target ratio, we employ a quadratic penalty function that lowers the bank's revenue in response to deviations (above or below) of the actual capital ratio from the required ratio. ${ }^{4}$ For example, in the event of a negative shock to capital relative to the target, (through a fall in capital or a rise in required capital), the penalty cost of deviating from the regulatory requirement creates an incentive to raise capital.

As discussed in greater detail below, banks can raise capital in a number of different ways. In the model used in this paper, the strategy for raising capital is determined exogenously, but the baseline strategy employed in the paper (including as a supplement to other means of satisfying capital requirements) involves banks increasing lending spreads in order to increase profits. However, the benefits of this approach in terms of reducing the penalty cost of deviating from the capital requirement must be balanced against the fact that it is also costly for banks to raise spreads, since they face a downward sloping demand for bank loans. Consequently, banks will tend to eliminate deviations of actual capital ratios from required ratios gradually rather than abruptly.

Bank capital requirements together with equity market imperfections (a constant dividend payout ratio) bring the bank capital channel into the model. This channel alters the transmission of policy interest rates if banks face a negative shock to their capital. In this event banks seek to

\footnotetext{
${ }^{4}$ See Appendix I, which provides further details on the structure of the model.
} 
accumulate additional capital and hence exercise an influence on interest rate spreads and credit availability independent of monetary policy. A similar mechanism is introduced through liquidity requirements, since changes in the target liquidity ratio affect bank profits and, consequently, interest rate spreads.

\section{An unexpected technology shock}

An unexpected temporary improvement in intermediate production technology lowers production costs. Profits of monopolistically competitive retailers increase as the production cost decreases are not fully passed through to consumer prices. Monetary policy reacts to the easing of inflation by lowering the nominal policy interest rate.

Consumption by both patient and impatient households increases. In the case of patient households, consumption rises and labor supply declines in response to lower consumer goods prices and higher dividend income from final goods retailers. The increase in consumption by impatient households is slightly less as they do not received dividend income. Higher consumption by both groups also includes demand for housing, leading to rising house prices.

Investment also rises. The technology shock raises the marginal product of capital, offering a higher rate of return on investment, while lower interest rates also boost the attractiveness of investment. Initially, however, much of the boost to investment has to be self-financed by entrepreneurs (by cutting their consumption), reflecting bank borrowing constraints. Rising capital goods prices, however, ease the borrowing constraint so that investment becomes increasingly loan-financed.

The banking system tends to dampen the expansion of activity in response to the productivity shock and easing in the monetary policy stance. In part this results from the fact that lower interest rates apply only to new loans (including rollovers), so that the impact of the lower interest rates feeds through only gradually into retail lending rates to households. In addition, however, as demand for loans by households and entrepreneurs increase, banks experience a decrease in capital adequacy ratios. In order to build up capital to support higher lending, banks increase spreads between borrowing and lending rates, diminishing somewhat the monetary policy stimulus. 
Figure 1. A Technology Shock
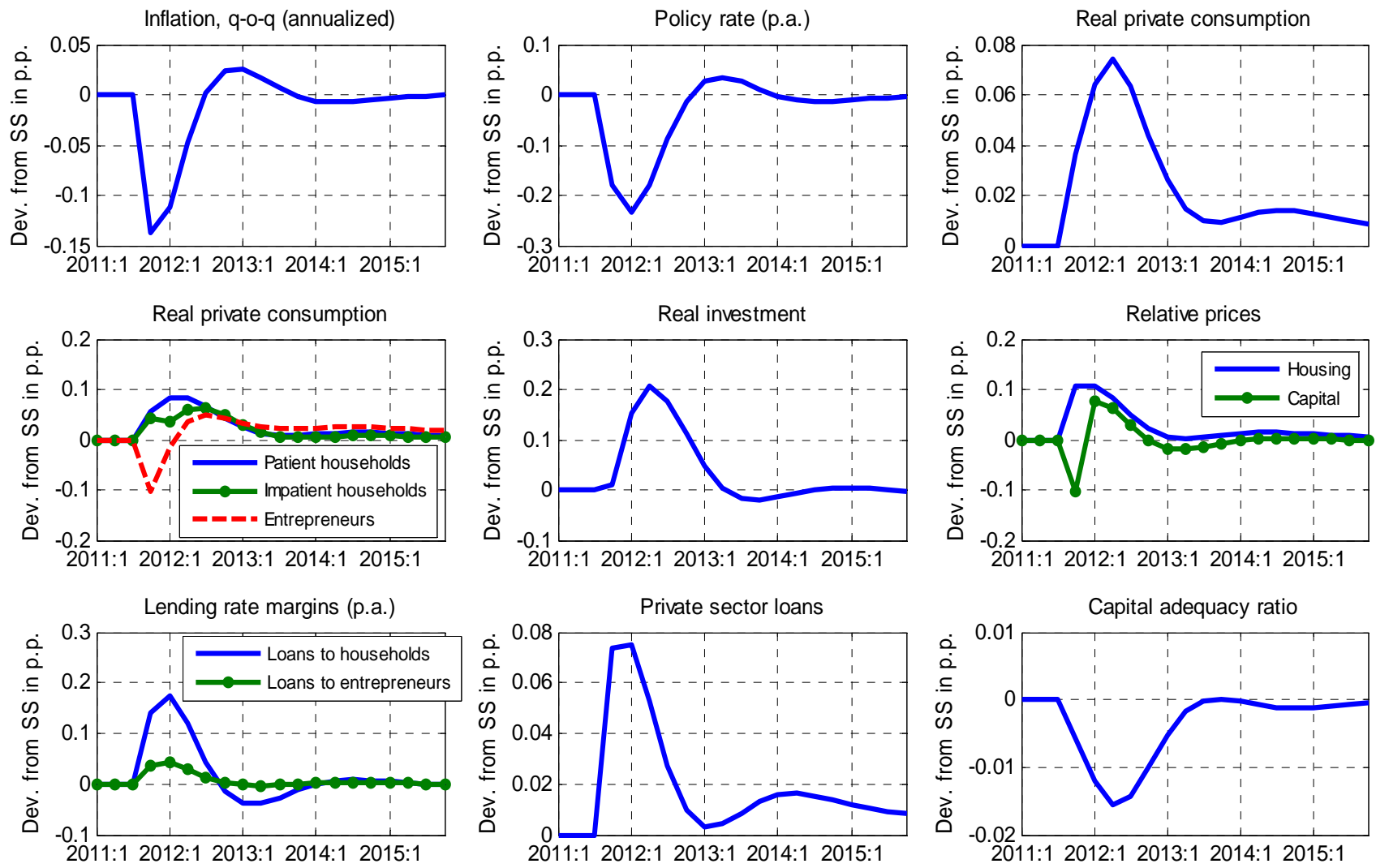

Source: Authors' calculations.

\section{MACROECONOMIC COSTS OF INCREASING CAPITAL AND LIQUIDITY REQUIREMENTS}

\section{A. Regulatory Changes and Assumptions}

The DGSE model outlined above was used to estimate the macroeconomic costs of:

- A 2 percentage point increase in the required capital ratio, defined as the ratio of tangible common equity (TCE) to risk-weighted assets (RWA);

- A 25 percent increase in bank liquidity requirements.

The increase in capital and liquidity requirements is assumed to be implemented in a linear fashion over policy implementation horizons of between 2 and 6 years. ${ }^{5}$ Moreover, the simulations treat the succession of incremental adjustments in the requirements as unanticipated

${ }^{5}$ The baseline analysis used for the paper is a 2 year implementation horizon. For the MAG analyses published in the Interim Report (MAG 2010a), implementation horizons of 2, 4, 6 year were used, with a 4 year baseline horizon. In the final report, the MAG added an 8-year implementation horizon, consistent with FSB/BCBS recommendations. 
shocks. This ensures that the bank responses will also be gradual, rather than front-loaded in response to the announcement, or anticipated announcement of the regulatory changes. It also means that private sector agents will not act in anticipation of bank responses to future increases in regulatory requirements.

To the extent that changes in regulatory requirements were anticipated, the volatility of the real economy would increase, but the cumulative cost, in terms of output losses, would remain approximately unchanged. The higher volatility of output would stem from strong consumption and investment responses to anticipated increases in borrowing costs. However, the subsequent declines in consumption and investment would also be steeper. The cumulative macroeconomic costs should be less than in the unanticipated case, reflecting agents' better information sets. However, the gain would likely be small as it seems unrealistic to assume that agents would be able to anticipate banks' behavior with certainty, and vice-versa.

Monetary policy is assumed to respond to the regulatory changes in so far as they change the outlook for inflation and activity. However, the monetary policy authorities, like the banks, are not assumed to have advance knowledge of the whole sequence of adjustments in regulatory requirements. To assess the importance of the monetary policy response in mitigating the effects of regulatory changes, an alternative set of simulations was run with an unchanged interest rate, so that monetary policy does not respond to the regulatory changes.

The magnitudes of the changes in capital and liquidity requirements are essentially arbitrary. The MAG (2010a) analysis considered a range of different increases, but only one is presented in this paper, as linearity of the model solution means that the effects of different capital and liquidity scenarios can be obtained by simply scaling up or down the reported results.

\section{B. Potential Bank Responses to an Increase in Capital Requirements}

Following the MAG analysis we consider, as a baseline scenario, a gradual increase in the TCE/RWA ratio by 2 percentage points over 2 years. Effects of lengthening the implementation horizon are considered as alternative scenarios.

In order to meet the higher capital adequacy ratio requirements, banks can:

- Increase retained earnings by:

- Raising average lending margins, while keeping dividends unchanged;

- Reducing dividend payments and/or return on equity;

- Increasing operating efficiency while keeping dividends unchanged;

- Reduce risk-weighted assets by:

- Cutting the overall size of their loan portfolios; 
- Shifting the composition of loan portfolios towards less risky assets.

- Issue new equity, implying a dilution of existing shareholder rights and a permanent increase in payments to shareholders.

We assess macroeconomic implications of different strategies with the exception of an increase in operating efficiency or a new equity issue. Although efficiency gains would offer a very low cost means of increasing capital, the likely magnitude of such gains seems likely to be inadequate in financial systems characterized by a fairly high degree of competition. Consequently, such gains are seen as likely to offer only a minor role in addressing capital adequacy. An equity issue offers a prompt way of raising capital, but is not considered, partly because the dynamic effects are essentially non-existent with this model, and because banks may consider equity issuance, and the dilution of existing shareholder rights, as a last resort measure.

The characterization of banks in the model does not allow for the preferred method of achieving target capital ratios to be determined endogenously. Consequently, our approach is to consider the implications of alternative adjustment strategies. In reality, banks are likely to use some combination of strategies, with the particular choice depending significantly on the amount of time available to meet the change in requirements.

\section{Results}

The results indicate that the size of the macroeconomic impact of a tightening of capital requirements varies substantially according to how banks respond to the regulatory change. The lowest costs are incurred if capital is raised through cutting bank dividends and the target rate of return on equity. However, raising capital through cutting dividends alone may not be sufficient if the timetable for raising capital is fairly short. In this case, faster, but more costly measures may also be needed. In particular, banks can also raise capital by widening interest spreads. The most costly means of raising capital ratios is found to be through adjustment in the level of assets (the denominator of the ratio). This strategy is most likely to be adopted when a very rapid adjustment in the capital ratio is required. However, it is also found that the cost of adjustment is much less if cuts in lending are to the riskiest clients.

\section{Increasing retained earnings via dividend policy and return on equity}

Under this strategy, banks are assumed to eliminate all dividends during the two year implementation period, using all retained profits to build up capital. Moreover, it is assumed that that banks lower the target long-run return on equity (ROE) and dividend payout ratio in order to accommodate the regulatory changes without a permanent widening of spreads. Over the twoyear implementation period, however, cutting dividends is insufficient to meet the target increase in capital adequacy, so the dividend cut is assumed to be supplemented with a (temporary) 
increase in bank lending spreads in order to increase profits available for boosting capital. ${ }^{6}$ In this scenario, peak increases in spreads are 100 basis points (b.p.) in the EA and 80 b.p. in the United States (Tables 2 and 3, and Figures 2 and 3). ${ }^{7}$

The increase in lending spreads induces a slowing of consumption and investment spending, partly offset by an easing in the stance of monetary policy as inflation pressures diminish.

Eventually, as the capital ratio approaches the target level, lending spreads are gradually reduced and dividend payments are also eventually restored. For spreads to be restored to their original level, however, the target long-run ROE must be reduced slightly, by an estimated 1.5 percentage points in both economies. The peak decline in output relative to potential in this scenario is 0.5 percentage points in the EA and 0.3 percentage points in the United States. The cumulative loss of output over the simulation horizon reaches a little over 1 percentage point of GDP in the EA and a little less in the United States.

Table 2. The Euro Area-Effects of Tighter Capital Requirements (2 p.p. Increase in Capital Requirements over 2 Years)

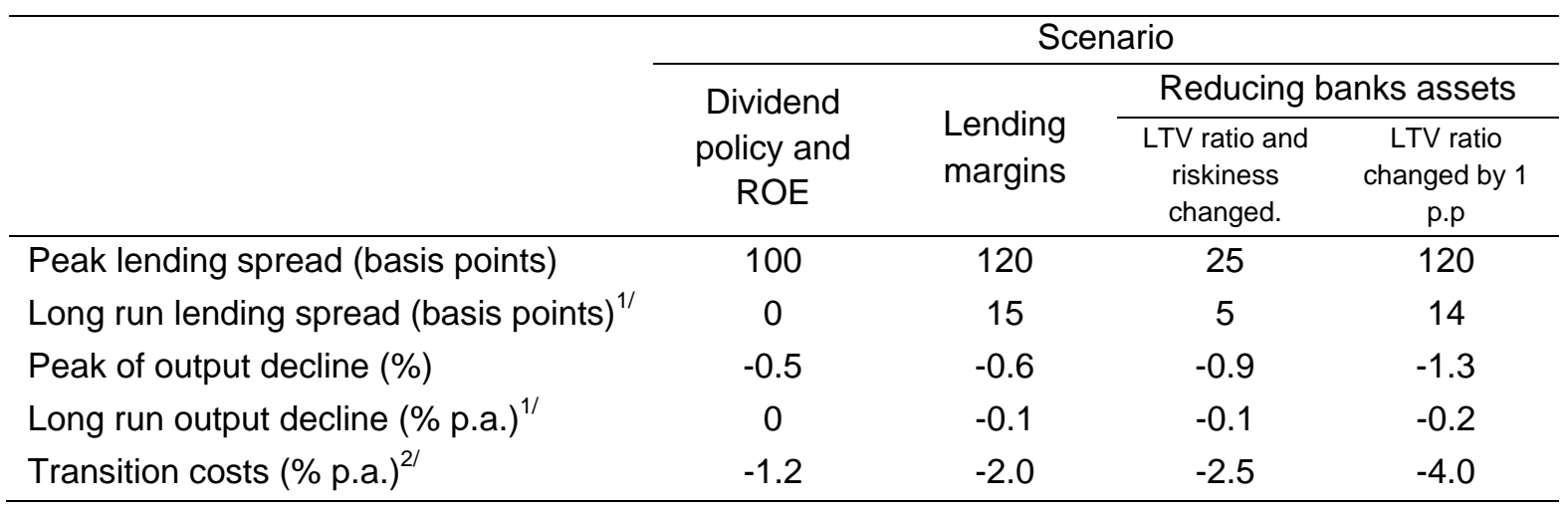

1/ Approximated by the end of 2018.

2/ Transition costs computed as cumulative output loss.

Source: Authors' calculations.

\footnotetext{
${ }^{6}$ The lending rate spread is computed as the difference of an average lending rate and the policy rate. The average lending rate is counted as a weighted average of rates on loans to households and entrepreneurs with weights equal to their shares on total loans.

${ }^{7}$ The lower interest rate increase in the U.S. reflects the higher dividend payout ratio for U.S. than EA banks, which allows U.S. banks to build up capital more quickly when dividends are reduced to zero.
} 


\section{Table 3. The United States-Effects of Tighter Capital Requirements}

(2 p.p. Increase in Capital Requirements over 2 Years)

\begin{tabular}{|c|c|c|c|c|}
\hline & \multicolumn{4}{|c|}{ Scenario } \\
\hline & \multirow{2}{*}{$\begin{array}{l}\text { Dividend } \\
\text { policy and } \\
\text { ROE }\end{array}$} & \multirow[b]{2}{*}{$\begin{array}{l}\text { Lending } \\
\text { margins }\end{array}$} & \multicolumn{2}{|c|}{ Reducing banks assets } \\
\hline & & & $\begin{array}{l}\text { LTV ratio and } \\
\text { riskiness } \\
\text { changed. }\end{array}$ & $\begin{array}{c}\text { LTV ratio } \\
\text { changed by } 1 \\
\text { p.p }\end{array}$ \\
\hline Peak lending spread (basis points) & 80 & 130 & 30 & 125 \\
\hline Long run lending spread (basis points) $^{1 /}$ & 0 & 20 & 5 & 18 \\
\hline Peak of output decline (\%) & -0.3 & -0.5 & -0.9 & -1.3 \\
\hline Long run output decline (\% p.a. $)^{1 /}$ & 0 & -0.1 & -0.2 & -0.2 \\
\hline Transition costs (\% p.a.) $)^{2 /}$ & -0.9 & -2.0 & -2.9 & -4.3 \\
\hline
\end{tabular}

1/ Approximated by the end of 2018.

2/ Transition costs computed as cumulative output loss.

Source: Authors' calculations.

\section{Increasing retained earnings via lending margins}

An alternative strategy is for the banks to maintain their dividend policy, but to build up capital by widening lending spreads in order to increase profits. This strategy was considered as the central strategy in the MAG analysis, partly because incorporating a widening of spreads is a relatively tractable exercise in models without explicit financial sectors. Nonetheless, the scenario was also considered sensible from an economic perspective, since the likely implementation period for capital increases was anticipated to be too short to rely on dividend cuts alone to build up capital, but long enough for widening of spreads to play a major role. Moreover, the scenario is considered middle-of-the-road in the sense that it would not involve transitional macroeconomic costs as low as would be achievable with strategies involving new equity issuance or cuts in dividends as the main means of raising capital ratios, but lower cost than the more drastic option of cutting lending to raise capital ratios.

In this scenario, banks need to raise lending spreads more than in the dividend cutting scenario. The simulations lead to a peak rise on lending spreads by 120 b.p. in the EA and by 130 b.p. in the United States (Tables $2 \& 3$ ). ${ }^{8}$ The larger increase in lending spreads leads to a somewhat larger adverse impact on consumption and investment than in the previous scenario (Figures $2 \&$ 3 ), with a peak decline in output of 0.6 percent in the EA and 0.5 percent in the United States.

\footnotetext{
${ }^{8}$ Note that the higher dividend payout ratio in the U.S. means that lending spreads need to be increased by more than in the EA, as more of the profit is paid out as dividends rather than retained in capital.
} 
A difference with the previous scenario is that lending spreads need to remain permanently higher in this scenario, reflecting the assumption of an unchanged long-run target for ROE. With the higher capital ratio, this requires lending spreads about 15-20 b.p. higher in the steady state. This helps to explain why the cumulative output cost of the strategy employed in this scenario is roughly double the cost under the previous scenario, in which spreads are unchanged in the long run. The higher long-run spread implies that the marginal product of capital also be slightly higher in the long run, which is reflected in a slightly lower steady state level of output.

\section{Adjusting banks assets}

A more drastic adjustment strategy is for banks to raise capital ratios by cutting risk-weighted assets. This strategy is most likely to be followed if banks have very little time in which to adjust capital ratios, since this would give little time to build up capital through dividend cuts or widening of lending margins.

The strategy is implemented in the model by banks cutting lending through a gradual reduction in target loan-to-value (LTV) ratios. As with the increase in lending spreads, the gradual reduction in LTV ratios implicitly recognizes the fact that such changes can only be implemented at the margin to new loans or loans being rolled over. It also implies that the magnitude of the decrease in the LTV ratio at the margin is much larger than the change in the average LTV ratio suggests, which partly explains why a relatively small reduction in the average LTV ratio appears to have such large effects.

Two variants of this strategy were examined. In the first variant, it was assumed that cuts in the LTV ratio would be applied across the board - that is, without regard to the risk-weighting of the loans involved. In this case, cuts in risk-weighted assets would be proportional to the overall cut in lending. The simulation results for this scenario suggest that a gradual, across-the-board cut in bank LTV ratios would lead to peak declines in lending

5.1 percent in the EA and by 6.4 percent in the United States (Figures 4 and 5). The simulations also indicate that, over a two year implementation period, the cutback in lending would be insufficient to raise capital ratios to the required level, so that a widening of margins would also be needed, and of nearly the same magnitude as under the strategy of using wider spreads alone to raise capital ratios.

The cut in bank lending under this strategy leads to sharp contractions in investment and consumption. The adverse demand effects are amplified as weaker spending leads to declines in asset values, cutting collateral values and access to credit. As a result, both economies experience peak contractions in real economic activity relative to potential of around 1.3 percentage points (Tables 2 and 3). Adverse effects on output measured by cumulative losses are approximately doubled comparing to the scenario with the adjustment of lending margins. More adverse output effects arise from a permanent fall in asset prices as they are less valuable for borrowers to purchase loans. The lower relative price of assets accentuates further the decline in access to bank lending. 
The second variant of this strategy considered is a more focused cut in bank lending. In particular, we consider a similar cut in bank lending, but concentrated on loans with a high risk weighting. In this case, risk-weighted assets would decline faster than total lending, allowing banks to increase their risk-weighted capital adequacy with a smaller contraction in total lending.

In the simulations, it was found that a cut in lending sufficient to lower the aggregate LTV ratio by 1 percentage point, could largely achieve the target increase in the capital ratio without a major widening of spreads if the cuts in lending yielded a 14 percent reduction in the average riskiness of the loan portfolio. ${ }^{9}$ In this case, lending spreads rise by nearly 100 b.p. less than if there is no change in portfolio riskiness, substantially lowering the peak and cumulative losses associated with the strategy of cutting the LTV ratio. The maximum output fall in both economies is reduced to a peak of 0.9 percentage points, while the cumulative output loss are about half of those in the first variant of the strategy (Figures 6 and 7).

\section{An Increase in Liquidity Requirements}

Changes in liquidity requirements have two important effects. First, since more liquid assets tend to have lower yields than less liquid assets, bank revenues decline as they raise holdings of liquid assets. This implies that, other things being equal, a wider spread would need to be associated with higher liquidity requirements in order for banks to maintain a given long-term target ROE. In addition, however, as holdings of liquid assets increase, banks' risk-weighted assets decline, allowing them to reduce capital. This tends to put downward pressure on spreads, partly offsetting the pure liquidity effect. As a result, higher liquidity and capital requirements tend to be complementary, so that their effects are not simply additive.

The MAG analysis considered an increase in liquidity requirements by 25 percentage points gradually over 2 years, leaving the definition of liquidity requirements to be based on relevant national requirements and definitions. In our simulations higher liquidity requirements are simulated by raising bank holdings of low yielding, highly liquid government securities relative to other, higher yielding but less liquid assets. Government bonds are assumed to be risk-free, so that changes in liquidity holds of banks also affect the average riskiness of bank assets. This, in turn, affects banks' fulfillment of capital requirements. Banks' target ROE and dividend policies are assumed to remain unaffected by changes in the required liquidity ratio.

To clarify and quantify the interaction of liquidity and capital requirements, the liquidity simulations include two variants. In one the capital requirement is assumed to be set in terms of equal risk weighting of all assets, so that changes in liquidity requirements have no impact on capital requirements. In the second variant, capital requirements are risk weighted, so that changes in liquidity requirements do affect risk-weighted capital positions. Comparison of the

\footnotetext{
${ }^{9}$ The drop in riskiness is ad-hoc and chosen to meet the target of capital requirements assuming 1 p.p. cut in the LTV ratio. The relation between the LTV ratio and the riskiness is left to further research.
} 
two variants allows us to distinguish between the "pure" liquidity requirement effect and interaction between liquidity and capital requirements.

In the baseline case, where changes in liquidity requirements affect risk-weighted assets, the rise in liquidity requirements leads to an immediate increase in bank holdings of government bonds, while preserving the amount of loans to the private sector in short run. In order to maintain the ROE target, spreads need to be increased. At the same time, the higher holdings of zero riskweighted government bonds lower average risk weighted assets, reducing capital needs. This reduction in capital requirements puts downward pressure on spreads. The net impact estimated in the model is that average interest rate spreads in the EA and United States economies rise by about 50 b.p.

Working through the same channels as described earlier in the case of capital requirements the increases in interest rate spreads implies moderate transitory costs. Peak declines in reach -0.2 percent in both economies as monetary policy dampens the real effects. The cumulative output loss reaches approximately 0.8 percent of GDP in the EA and 1 percent in the United States (Tables 4 and 5, and Figure 8).

Over the longer term, as loan volumes adjust to the slowing of activity and widening of spreads, further reductions in capital are feasible, allowing spreads to narrow. Nonetheless, with a higher share of low yielding assets in their asset portfolios, lending spreads remain permanently wider. In the case of the United States, with a higher target ROE and dividend payout ratio than in the EA, the long-run impact on spreads are larger, at around 20 b.p., compared with just 5 b.p. in the EA.

The moderate effect of tighter liquidity largely reflects favorable implications on capital requirements via risk weights. Simulations of higher liquidity requirements but without allowing capital requirements to be affected by changes in the riskiness of assets suggest that this offset be substantial. In the absence of the offset, the estimated impact of higher liquidity requirements would be 3 to 4 times as large as the simulations with the offset, with proportionately larger effects on output (Tables 4 and 5, and Figures 9 and 10). 
Table 4. The Euro Area-Effects of Tighter Liquidity Requirements

(25 p.p. Increase in Liquidity Requirements over 2 Years)

\begin{tabular}{lcc}
\hline & \multicolumn{2}{c}{ Scenario } \\
\cline { 2 - 3 } & Baseline & $\begin{array}{c}\text { No effects on } \\
\text { riskiness }\end{array}$ \\
\hline Peak lending spread (basis points) & 50 & 180 \\
Long run lending spread (basis points) & 5 & 20 \\
Peak of output decline (\%) & -0.2 & -0.9 \\
Long run output decline (\% p.a.) & -0.0 & -0.1 \\
Transition costs (\% p.a.) & -0.8 & -3.0 \\
\hline
\end{tabular}

1/ Approximated by the end of 2018.

2/ Transition costs computed as cumulative output loss.

Source: Authors' calculations.

\section{Table 5. The Unites States-Effects of Tighter Liquidity Requirements}

(25 p.p. Increase in Liquidity Requirements over 2 Years)

\begin{tabular}{lcc}
\hline & \multicolumn{2}{c}{ Scenario } \\
\cline { 2 - 3 } & Baseline & $\begin{array}{c}\text { No effects on } \\
\text { riskiness }\end{array}$ \\
\hline Peak lending spread (basis points) & 60 & 195 \\
Long run lending spread (basis points) & 20 & 40 \\
Peak of output decline (\%) & -0.2 & -0.7 \\
Long run output decline (\% p.a.) & -0.1 & -0.2 \\
Transition costs (\% p.a.) & -1.1 & -3.2 \\
\hline
\end{tabular}

1/ Approximated by the end of 2018.

2/ Transition costs computed as cumulative output loss.

Source: Authors' calculations.

There are several limitations of the model in the description of liquidity requirements with potential implications for the robustness of the results. In particular, the exercise assumes that banks are able to adjust their liquidity positions immediately, as the government is willing to supply any amount of liquid securities at any level of the interest rate. Additionally, the model exhibits the property of Ricardian equivalence and, therefore, the implicit public debt operations corresponding to the liquidity changes by banks have no substantive real effects. Finally, the description of government balance sheet is quite simple and schematic. Effects of higher government bond holding by commercial banks on public debt financing are not considered. 


\section{E. Sensitivity and Robustness Analysis}

The MAG analyses considered a number of variations on the main assumptions. These included

- Variations in the magnitude of the increases in capital and liquidity requirements;

- Variation in the length of the implementation horizon;

- $\quad$ The scope for monetary policy actions during the implementation period; and

- $\quad$ The speed of bank responses to the regulatory measures.

Simulations to test the sensitivity of these assumptions suggest that:

- The effects of variations in the magnitude of changes in requirements are essentially proportional to the changes in requirements, essentially reflecting the fact that the simulation model is locally linear;

- $\quad$ Lengthening the implementation period would dampen the magnitude of interest rate and macroeconomic effects, as would a more gradual adjustment of bank capital and liquidity towards the targets, but the cumulative effects on output would be essentially similar, again reflecting the linearity of the model;

- $\quad$ The scope for monetary policy to respond to changes in requirements is important. If monetary policy is unable to respond, the peak impact of such measures could be roughly twice as large as in the scenarios with monetary policy responses;

- Faster adjustment of banks to changes in regulatory targets would raise the real costs of implementation over the short term.

\section{Effects of capital and liquidity tightening under different implementation horizons}

MAG simulations of tighter capital and liquidity standards used a range of between 2- and 8years for the implementation period. The main results in this paper are shown for a 2-year implementation period. Extending the implementation horizon for capital increases to 4-years reduces the peak effect on growth by approximately one-third, but has little effect on the cumulative loss (Tables 6 and 7, Figures 11 and 12). The simulations suggest that lengthening of the implementation horizon might reduce the transition costs only when banks experience high ROE and retain all dividends (see, e.g., the United States case in Table 7). 


\section{Table 6. The Euro Area-Effects of Tighter Capital Requirements over Different Horizons}

(2 p.p. Increase in Capital Requirements)

\begin{tabular}{|c|c|c|c|c|c|c|c|c|}
\hline \multirow[b]{4}{*}{ Implementation horizon (in years) } & \multicolumn{8}{|c|}{ Scenario } \\
\hline & \multirow{2}{*}{\multicolumn{2}{|c|}{$\begin{array}{l}\text { Dividend } \\
\text { policy and } \\
\text { ROE }\end{array}$}} & \multirow{2}{*}{\multicolumn{2}{|c|}{$\begin{array}{l}\text { Lending } \\
\text { margins }\end{array}$}} & \multicolumn{4}{|c|}{ Reducing banks assets } \\
\hline & & & & & \multicolumn{2}{|c|}{$\begin{array}{c}\text { LTV ratio } \\
\text { and riskiness } \\
\text { changed }\end{array}$} & \multicolumn{2}{|c|}{$\begin{array}{l}\text { LTV ratio } \\
\text { changed by } \\
1 \text { p.p. }\end{array}$} \\
\hline & 2 & 4 & 2 & 4 & 2 & 4 & 2 & 4 \\
\hline Peak lending spread (basis points) & 100 & 50 & 120 & 80 & 25 & 15 & 120 & 75 \\
\hline $\begin{array}{l}\text { Long run lending spread (basis } \\
\text { points)* }\end{array}$ & 0 & 0 & 15 & 15 & 5 & 5 & 14 & 14 \\
\hline Peak output decline (\%) & -0.5 & -0.3 & -0.6 & -0.4 & -0.9 & -0.5 & -1.3 & -0.8 \\
\hline Long run output decline (\% p.a.) $)^{1 /}$ & 0 & 0 & -0.1 & -0.1 & -0.1 & -0.1 & -0.2 & -0.2 \\
\hline Transition costs (\% p.a. $)^{2 /}$ & -1.2 & -1.0 & -2.0 & -1.9 & -2.5 & -2.4 & -4.0 & -3.8 \\
\hline
\end{tabular}

1/ Approximated by the end of 2018.

2/ Transition costs computed as cumulative output loss.

Source: Authors' calculations.

\section{Table 7. The United States-Effects of Tighter Capital Requirements over Different Horizons}

(2 p.p. Increase in Capital Requirements)

\begin{tabular}{|c|c|c|c|c|c|c|c|c|}
\hline \multirow[b]{4}{*}{ Implementation horizon (in years) } & \multicolumn{8}{|c|}{ Scenario } \\
\hline & \multirow{2}{*}{\multicolumn{2}{|c|}{$\begin{array}{l}\text { Dividend } \\
\text { policy and } \\
\text { ROE }\end{array}$}} & \multirow{2}{*}{\multicolumn{2}{|c|}{$\begin{array}{l}\text { Lending } \\
\text { margins }\end{array}$}} & \multicolumn{4}{|c|}{ Reducing banks assets } \\
\hline & & & & & \multicolumn{2}{|c|}{$\begin{array}{l}\text { LTV ratio and } \\
\text { riskiness } \\
\text { changed }\end{array}$} & \multicolumn{2}{|c|}{$\begin{array}{c}\text { LTV ratio } \\
\text { changed by } \\
1 \text { p.p. }\end{array}$} \\
\hline & 2 & 4 & 2 & 4 & 2 & 4 & 2 & 4 \\
\hline Peak lending spread (basis points) & 80 & 30 & 130 & 90 & 30 & 15 & 125 & 85 \\
\hline $\begin{array}{l}\text { Long run lending spread (basis } \\
\text { points)* }\end{array}$ & 0 & 0 & 20 & 20 & 5 & 5 & 18 & 18 \\
\hline Peak output decline (\%) & -0.3 & -0.2 & -0.5 & -0.4 & -0.9 & -0.6 & -1.3 & -0.8 \\
\hline Long run output decline (\% p.a.) $)^{1 /}$ & 0 & 0 & -0.1 & -0.1 & -0.2 & -0.2 & -0.2 & -0.2 \\
\hline Transition costs (\% p.a.) $)^{2 l}$ & -0.9 & -0.3 & -2.0 & -1.9 & -2.9 & -2.7 & -4.3 & -4.0 \\
\hline
\end{tabular}

1/ Approximated by the end of 2018.

2/ Transition costs computed as cumulative output loss.

Source: Authors' calculations. 
Similarly, in the case of raising liquidity requirements, increasing the length of the implementation period to 4-years reduces the peak impact on lending margins by about onethird, thereby mitigating the real output costs in the short-run (Figures 13 and 14). The cumulative output costs, however, are not significantly reduced by lengthening the implementation period (Table 8).

\section{Table 8. Effects of Tighter Liquidity Requirements over Different Horizons} (25 p.p. Increase in Liquidity Requirements)

\begin{tabular}{lcccc}
\hline & \multicolumn{2}{c}{ EA } & \multicolumn{2}{c}{ U.S. } \\
Implementation horizon (in years) & 2 years & 4 years & 2 years & 4 years \\
\hline Peak lending spread (basis points) & 50 & 30 & 60 & 45 \\
Long run lending spread (basis points) & 5 & 5 & 20 & 20 \\
Peak of output decline (\%) & -0.2 & -0.2 & -0.2 & -0.2 \\
Long run output decline (\% p.a.) & -0.0 & -0.0 & -0.1 & -0.1 \\
Transition costs (\% p.a.) & -0.8 & -0.8 & -1.1 & -1.0 \\
\hline
\end{tabular}

1/ Approximated by the end of 2018.

2/ Transition costs computed as cumulative output loss.

Source: Authors' calculations.

\section{Effects of capital and liquidity tightening with alternative monetary policies}

The simulations presented in the previous parts assume that monetary policy can and does respond to developments in inflation and output following a standard Taylor type monetary policy rule. Since the regulatory and liquidity measures evaluated lead to tighter financing conditions for firms and households, both output and inflation tend to fall in response to the regulatory measures. In response, the monetary authority cuts its policy rate to counter the macroeconomic effects of the regulatory measures. Consequently, when monetary policy is able to respond to the implementation of regulations, it can mitigate part of the output effects of the regulatory measures. ${ }^{10}$ However, if monetary policy does not respond to the regulatory measures - for example, if interest rates were effectively constrained by being close to zero, then the output effects of regulatory measures would be larger. Simulations assuming no monetary policy response to the higher capital requirements suggest that both the peak and cumulative output losses in the Euro Area and United States economies would be substantially higher than if monetary policy is able to respond. As shown in Tables 9 and 10, the peak output decline with no monetary policy response is typically around 50 percent higher than with a policy response,

\footnotetext{
${ }^{10}$ More aggressive monetary policy would be needed to fully offset real effects and disinflationary pressures arising from regulatory changes. Due to transmission lags and real rigidities such a strategy might be very costly.
} 
while the cumulative output cost is around 25 percent higher (see also figures 15 and 16). Broadly similar results are found for an increase in liquidity requirements (Table 11).

\section{Table 9. The Euro Area-Effects of Tighter Capital Requirements under Alternative Monetary Policy}

(2 p.p. Increase in Capital Requirements over 2 Years)

\begin{tabular}{|c|c|c|c|c|c|c|c|c|}
\hline \multirow[b]{4}{*}{ Monetary policy } & \multicolumn{8}{|c|}{ Scenario } \\
\hline & \multirow{2}{*}{\multicolumn{2}{|c|}{$\begin{array}{l}\text { Dividend } \\
\text { policy and } \\
\text { ROE }\end{array}$}} & \multirow{2}{*}{\multicolumn{2}{|c|}{$\begin{array}{l}\text { Lending } \\
\text { margins }\end{array}$}} & \multicolumn{4}{|c|}{ Reducing banks assets } \\
\hline & & & & & \multicolumn{2}{|c|}{$\begin{array}{l}\text { LTV ratio and } \\
\text { riskiness } \\
\text { changed }\end{array}$} & \multicolumn{2}{|c|}{$\begin{array}{c}\text { LTV ratio } \\
\text { changed by } \\
1 \text { p.p. }\end{array}$} \\
\hline & On & Off & On & Off & On & Off & On & Off \\
\hline Peak lending spread (basis points) & 100 & 85 & 120 & 110 & 25 & 20 & 120 & 95 \\
\hline Long run lending spread (basis points) & 0 & 0 & 15 & 15 & 5 & 5 & 14 & 14 \\
\hline Peak output decline (\%) & -0.5 & -0.8 & -0.6 & -0.9 & -0.9 & -1.2 & -1.3 & -1.9 \\
\hline Long run output decline (\% p.a.) $)^{1 /}$ & 0 & 0 & -0.1 & -0.1 & -0.1 & -0.1 & -0.2 & -0.2 \\
\hline Transition costs (\% p.a.) $)^{2 /}$ & -1.2 & -1.6 & -2.0 & -2.5 & -2.5 & -3.3 & -4.0 & -5.1 \\
\hline
\end{tabular}

1/ Approximated by the end of 2018.

2/ Transition costs computed as cumulative output loss.

Source: Authors' calculations.

\section{Table 10. The United States- Effects of Tighter Capital Requirements under Alternative Monetary Policy}

(2 p.p. Increase in Capital Requirements over 2 Years)

\begin{tabular}{|c|c|c|c|c|c|c|c|c|}
\hline \multirow[b]{4}{*}{ Monetary policy } & \multicolumn{8}{|c|}{ Scenario } \\
\hline & \multirow{2}{*}{\multicolumn{2}{|c|}{$\begin{array}{l}\text { Dividend } \\
\text { policy and } \\
\text { ROE }\end{array}$}} & \multirow{2}{*}{\multicolumn{2}{|c|}{$\begin{array}{l}\text { Lending } \\
\text { margins }\end{array}$}} & \multicolumn{4}{|c|}{ Reducing banks assets } \\
\hline & & & & & \multicolumn{2}{|c|}{$\begin{array}{l}\text { LTV ratio and } \\
\text { riskiness } \\
\text { changed }\end{array}$} & \multicolumn{2}{|c|}{$\begin{array}{l}\text { LTV ratio } \\
\text { changed by } \\
1 \text { p.p. }\end{array}$} \\
\hline & On & Off & On & Off & On & Off & On & Off \\
\hline Peak lending spread (basis points) & 80 & 75 & 130 & 125 & 30 & 25 & 125 & 115 \\
\hline Long run lending spread (basis points) & 0 & 0 & 20 & 20 & 5 & 5 & 18 & 18 \\
\hline Peak output decline (\%) & -0.3 & -0.5 & -0.5 & -0.8 & -0.9 & -1.5 & -1.3 & -2.1 \\
\hline Long run output decline (\% p.a.) $)^{1 /}$ & 0 & 0 & -0.1 & -0.1 & -0.2 & -0.2 & -0.2 & -0.2 \\
\hline Transition costs (\% p.a.) $)^{2 /}$ & -0.9 & -1.2 & -2.0 & -2.5 & -2.9 & -4.2 & -4.3 & -6.1 \\
\hline
\end{tabular}

1/ Approximated by the end of 2018.

2/ Transition costs computed as cumulative output loss.

Source: Authors' calculations. 


\section{Table 11. Effects of Tighter Liquidity Requirements under Alternative Monetary Policy}

(25 p.p. Increase in Liquidity Requirements over 2 Years)

\begin{tabular}{lcccc}
\hline & \multicolumn{2}{c}{ EA } & \multicolumn{2}{c}{ U.S. } \\
Monetary policy & On & Off & On & Off \\
\hline Peak of the lending spread (basis points) & 50 & 40 & 60 & 55 \\
Lending spread in long-run (basis points) $^{1 /}$ & 5 & 5 & 20 & 20 \\
Peak of output decline (\%) & -0.2 & -0.4 & -0.2 & -0.3 \\
${\text { Output decline in the long-run (\% p.a.) })^{1 /}}_{\text {Transition costs (\% p.a.) }}^{2 /}$ & -0.0 & -0.0 & -0.1 & -0.1 \\
\hline
\end{tabular}

1/ Approximated by the end of 2018.

2/ Transition costs computed as cumulative output loss.

Source: Authors' calculations.

\section{The sensitivity of results to the speed of adjustment to higher capital requirements}

The impact of changes in regulatory requirements on economic activity is largely driven by the pass-through of regulatory requirements into spreads between bank lending rates and their costs of funds. An important issue in bank behavior is how quickly they can be expected to adjust to changes in capital requirements. More rapid adjustment implies greater adjustments in interest rate spreads in order to generate the additional profits needed to build up capital more quickly than otherwise. It also implies that capital buffers over and above requirements would need to play a smaller role (be less squeezed) than with a more gradual process of adjustment to higher capital requirements.

The speed of adjustment used in the model can be compared with empirical studies estimating the speed of convergence of actual capital ratios towards estimated target levels. These studies assume that adjustment costs preclude banks from achieving the target level immediately and suppose a gradual adjustment described by equation (1).

$$
k_{t}=\lambda k_{t-1}+(1-\lambda) k_{t-1}^{*}
$$

Where:

$k$ denotes the actual capital/asset ratio

$k^{*}$ stands for the target ratio.

Estimates of equation (1) suggest a fairly high degree of persistence ranging from 0.42 to 0.97 , implying only gradual adjustment of capital ratios towards targets (Table 12). The relatively wide range of results may reflect diverse sets of shocks as well as differences in bank strategies to accommodate regulatory requirements. 
The estimates of the adjustment coefficient for the U.K. and Germany are very different, providing little guidance to calibration of the model for the EA (Figure 17). The calibration in the model for the United States is above the upper part of 95 percent confidence bands found by Berrospide and Edge (2010) as shown in Figure 18.

Simulations to assess the sensitivity of results to variations in the speed of adjustment towards target capital ratios suggests that lowering the adjustment parameter by 50 percent from the baseline value would reduce peak interest rate margins by about 50 basis points relative to the baseline case in both economies. The lower interest rate spreads, in turn, would cushion the output effects, dampening the peak decline in output in both economies by around $1 / 2$ p.p. in both economies (Figures 19 and 20).

Table 12. Persistence of the Capital Adequacy Ratio

\begin{tabular}{lcc}
\hline \multicolumn{1}{c}{ Paper } & Country & Persistence \\
\hline Berrospide and Edge (2010) & U.S. & 0.91 \\
Francis and Osborne (2009) & U.K. & 0.97 \\
Memmel and Raupach (2007) & Germany & 0.42 \\
\hline
\end{tabular}

Source: Authors' calculations.

Changes in the speed of adjustment, however, do not change the long-term implications. The slower pace of adjustment basically extends the period over which slower growth is experienced and bank capital buffers may need to cushion the discrepancy between desired and required capital. The simulations therefore point to the issue of the extent to which bank capital buffers above and beyond requirements are likely to play a significant role in the transition process.

\section{Concluding Comments And Future Directions}

The analysis in this paper was used in conjunction with a range of other models to form an assessment of the potential impact of higher capital and liquidity requirements. In contrast with most other models used in the MAG analysis, the DSGE model used in this paper included an explicit financial sector, as well as bank capital and liquid assets. As a result, it was feasible to examine the implications of changes in capital and liquidity requirements, either independently or together, within a consistent framework. The framework also provided a consistent basis for examining alternative adjustment strategies by banks.

The results of the analyses were generally consistent with those of other approaches, although the magnitudes of effects were typically a little larger than found using semi-structural models. The fact that the results using this type of model were comparable to those of semi-structural models lends confidence to the use of DSGE models in policy-oriented analysis of macrofinancial issues. The DSGE framework with an explicit financial sector allowed the model to be used in ways that were essentially impossible with semi-structural models. In particular, the model was able to be used to examine the interaction of capital and liquidity requirements, as 
well as the impact of alternative adjustment strategies by banks to changes in regulatory requirements.

Nonetheless, there is still far to go in developing such models and using them to analyze interactions between macro-prudential measures, financial developments, and macroeconomic performance. An obvious limitation of this model is the fact that it is a closed economy model. Additionally, the model does not explicitly deal with risk. In particular, there is no explicit representation in portfolios of different risk classes of assets, other than risk-free government securities. Moreover, risks of default, and the balance sheet consequences and transmission of defaults or loan impairment are not represented. A third important area in which the model is lacking is with regard to the interaction of financial developments with the public sector fiscal accounts. As is being seen in Europe, financial stress in the financial sector can spill over into the public sector, with strong feedback loops through interest rate risk premia. The final area in which further development is clearly needed is the incorporation of the non-bank financial sector. In this model, the stylized bank is generic enough to capture similar behavior of nonbanks, but it does not capture the behavior and balance sheets of pensions, insurance, and other such financial institutions, and there is no equity market in the model. 


\section{References}

Basel Committee on Banking Supervision (BCBS), 2010, "An Assessment of the Long-Term Impact of Stronger Capital and Liquidity Requirements-LEI Report.” Basel, August.

Benes, Jaromir, and Kirdan Lees. 2007, "Monopolistic Banks and Fixed Rate Contracts: Implications for Open Economy Inflation Targeting.” RBNZ, unpublished mimeo.

Berrospide, Jose, and Rochelle Edge. 2010, "The effects of bank capital on lending: What do we know? And, what does it mean?" Finance and Economics Discussion Series 2010, pp.44, Board of Governors of the Federal Reserve System (Unites States).

Calza, Alessandro, Tommaso Monacelli, and Livio Stracca. 2007. "Mortgage Markets, Collateral Constraints, and Monetary Policy: Do Institutional Factors Matter?" CEPR Discussion Papers 6231.

Christiano, Lawrence, Roberto Motto, and Massimo Rostagno. 2008. "Shocks, structures or monetary policies? The Euro Area and U.S. after 2001." Journal of Economic Dynamics and Control, 32(8): 2476-2506.

Francis, William, and Matthew Osborne. 2009, "Bank Regulation, Capital and Credit Supply: Measuring the Impact of Prudential Standards." Financial Services Authority Occasional Papers 36.

Gerali, Andrea, Stefano Neri, Luca Sessa, and Federico Signoretti. 2010. "Credit and banking in a DSGE model of the euro area." Bank of Italy, Economic Research Department Temi di discussione (Economic working papers) 740.

Erceg, Christopher, Dale Henderson, and Andrew Levin. 1999. "Optimal Monetary Policy with Staggered Wage and Price Contracts.” Journal of Monetary Economics, Vol, 46, pp. $281-313$.

Iacoviello, Matteo. 2005, "House Prices, Borrowing Constraints, and Monetary Policy in the Business Cycle." American Economic Review, Vol. 95(3), pp. 739-764.

Iacoviello, Matteo, and Stefano Neri, 2010, "Housing Market Spillovers: Evidence from an Estimated DSGE Model." American Economic Journal: Macroeconomics, Vol. 2, pp. $125-164$.

Kocherlakota, Narayana, 2000, "Creating business cycles through credit constraints." Federal Reserve Bank of Minneapolis Quarterly Review, Vol. 24(3), pp. 2-10.

Macroeconomic Assessment Group (MAG), 2010a. "Assessing the Macroeconomic Impact of the transition to Stronger Capital and Liquidity Requirements-Interim Report.” group 
established by the Financial Stability Board and the Basel Committee on Banking Supervision, August.

Macroeconomic Assessment Group (MAG), 2010b. "Assessing the Macroeconomic Impact of the transition to Stronger Capital and Liquidity Requirements-Final Report." group established by the Financial Stability Board and the Basel Committee on Banking Supervision, December.

Memmel, Christoph and Peter Raupach, 2007. "How do banks adjust their capital ratios? Evidence from Germany." Discussion Paper Series 2: Banking and financial studies. Deutsche Bundesbank. 


\section{Appendix I. A Description of the Model and Calibration}

The model used to assess implications of regulatory measures is a closed economy DSGE model with financial frictions and banks facing capital and liquidity requirements. Financial frictions relate particularly to the lending and the balance sheet channel assuming that households and entrepreneurs finance part of their expenditures using bank loans. Using the collateral constraint framework of Iacoviello (2005), with a limited contract enforcement environment, household borrowing is collateralized by housing, while entrepreneurs use productive capital to secure their borrowing.

Following Gerali et al. (2010), loans are extended by commercial banks. Banks use deposits from households and their own capital to make loans to entrepreneurs and other households. They have to meet regulatory requirements comprising capital adequacy and liquidity ratios. The capital adequacy ratio is defined in terms of bank capital relative to risk-weighted assets. As it is costly for banks to issue equity, capital requirements alter the transmission of shocks, introducing the bank capital channel. The liquidity requirement is defined in terms of liquid assets - government bonds - relative to total bank assets.

Besides financial frictions and a banking sector, the model includes a standard set of real and nominal frictions. In the model monetary policy is assumed to maintain an inflation target following an interest rate rule.

\section{A. Model Structure and Behavior}

The model economy is made up of patient and impatient households, entrepreneurs, final goods producers, banks, government, and a monetary policy authority. Employment intermediaries, labor and final goods aggregators, and capital producers are introduced in order to simplify the optimization problems and facilitate the derivation of the model. Model equations consist of first order conditions of optimization problems listed below. To keep the exposition of the model simple, stochastic shocks are removed from the derivation below.

\section{Households}

There are two types of households assumed in the model, differing in their deterministic discount factors. This difference ensures both borrowing and lending by the household sector in the steady state. Patient households, with a high discount factor, save by holding deposits with banks. Impatient households have a lower deterministic discount factor and use bank loans to finance their expenditures. Both types of household derive utility from consumption and housing. Housing generates wealth effects, as house price movements affect consumption. Each type of household consists of a continuum of monopolistically competitive agents, each of which supplies differentiated labor. Monopolistic competition in the labor market provides the basis for sticky nominal wages. 
Patient households use deposits and housing to smooth their consumption. They consume final consumption goods $c_{t}^{p}$, supply a specific type of labor $l_{t}^{p}$, demand housing $h_{t}^{p}$ and supply deposits $d_{t}$. Patient households own all firms and banks in the model, receiving firms' and banks' profits $\Pi_{t}$, lump-sum transfers from government $\Gamma_{t}$ and net labor income insurance $V_{t}^{p}$.

The $j$-th household maximizes the following discounted sum of its utility subject to a household budget constraint:

$$
E_{0} \sum_{t=0}^{\infty} \beta_{p}^{t}\left[\ln \left(c_{t}^{p}(j)-\rho^{h} \bar{c}_{t-1}^{p}\right)+\eta^{h} \ln \left(h_{t}^{p}(j)\right)-l_{t}^{p}(j)\right] \underset{c_{t}^{p}(j), h_{t}^{p}(j), d_{t}(j)}{\longrightarrow} \max
$$

s.t.

$$
\begin{aligned}
p_{t} c_{t}^{p}(j)+q_{t}^{h} & h_{t}^{p}(j)+p_{t} d_{t}(j)+\frac{\kappa^{h}}{2}\left(\frac{h_{t}^{p}(j)}{h_{t-1}^{p}(j)}-1\right)^{2} h_{t}^{p}(j)= \\
& =w_{t}^{p}(j) l_{t}^{p}(j)+q_{t}^{h} h_{t-1}^{p}(j)+\left(1+i_{t-1}^{d}\right) p_{t-1} d_{t-1}(j)+\Pi_{t}+\Gamma_{t}+V_{t}^{p}(j)
\end{aligned}
$$

Where $p_{t}$ is the final goods price, $q_{t}^{h}$ the price of housing, $w_{t}^{p}$ the nominal wage index and $i^{d}$ is a nominal interest rate on household deposits. External habit formation is assumed with a habit persistence coefficient of $\rho^{h}$, so that current consumption depends partly on past aggregate consumption of patient households $\bar{c}_{t}^{p}$. The term $\beta_{p}$ denotes the deterministic discount factor and $\eta^{h}$ is a scaling factor for housing in utility.

Patient households hold housing as it brings utility gains. They experience costs

$\frac{\kappa^{h}}{2}\left(\frac{h_{t}^{p}}{h_{t-1}^{p}}-1\right)^{2} h_{t}^{p}$ when adjusting their holding of housing. The adjustment costs capture market rigidities which attenuate the volatility of housing demand. The supply of housing is kept constant at the level $\bar{h}$ in the model economy and therefore house prices are determined only by household demand. ${ }^{11}$ Moreover, the fixed endowment of housing makes the growth of house prices more volatile than the growth of final consumer prices, and simplifies the structure of the model and the solution of the steady state. Assuming that housing is traded only between patient and impatient households the following identity holds:

$$
\bar{h}=h_{t}^{p}+h_{t}^{i}
$$

\footnotetext{
${ }^{11}$ Iacoviello and Neri (2010) claimed that slow technological progress in housing sector explains the upward trend in real house prices in the U.S.. The presumption of constant supply of housing is broadly in line with these empirical findings as the observed trend in relative prices suggests that the growth of real housing is moderate comparing to real economy.
} 
The first order conditions of the patient household optimization problem consists of the budget constraint and following equations: ${ }^{12}$

$$
\begin{gathered}
\lambda_{t}^{p}(j)=\frac{1}{c_{t}^{p}(j)-\rho^{h} \bar{c}_{t-1}^{p}} \\
\frac{\eta^{h}}{h_{t}^{p}(j)}+\lambda_{t+1}^{p}(j) \beta_{p}\left[q_{t+1}^{h}+\kappa_{h}\left(\frac{h_{t+1}^{p}(j)}{h_{t}^{p}(j)}-1\right)\left(\frac{h_{t+1}^{p}(j)}{h_{t}^{p}(j)}\right)^{2}\right]= \\
=\lambda_{t}^{p}(j)\left[q_{t}^{h}+\kappa_{h}\left(\frac{h_{t}^{p}(j)}{h_{t-1}^{p}(j)}-1\right) \frac{h_{t}^{p}(j)}{h_{t-1}^{p}(j)}+\frac{\kappa_{h}}{2}\left(\frac{h_{t}^{p}(j)}{h_{t-1}^{p}(j)}-1\right)^{2}\right] \\
\lambda_{t}^{p}(j)=\lambda_{t+1}^{p}(j) \beta_{p}\left(1+i_{t}^{d}\right)
\end{gathered}
$$

Where $\lambda_{t}^{p}$ is the Lagrange multiplier of the optimization problem. The index $j$ can be dropped as consumption, saving, and labor income adjusted by net labor subsidies are identical across patient households.

Impatient households take loans from banks and use housing as collateral. Housing also yields utility directly. Since impatient households hold no bank deposits, loans collateralized with housing are their only means of intertemporal smoothing of consumption. Impatient households consume final consumption goods $c_{t}^{i}$, offer a specific type of labor $l_{t}^{i}$, demand housing $h_{t}^{i}$ and loans $b_{t}^{i}$. The $j$-th household maximizes its lifetime utility function:

$$
E_{0} \sum_{t=0}^{\infty} \beta_{i}^{t}\left[\ln \left(c_{t}^{i}(j)-\rho^{h} \bar{c}_{t-1}^{i}\right)+\eta^{h} \ln \left(h_{t}^{i}(j)\right)-l_{t}^{i}(j)\right] \underset{c_{t}^{i}(j), h_{t}^{i}(j), b_{t}^{i}(j)}{\longrightarrow} \max
$$

s.t.

$$
\begin{gathered}
p_{t} c_{t}^{i}(j)+q_{t}^{h} h_{t}^{i}(j)+\left(1+i_{t-1}^{b i}\right) b_{t}^{i}(j) p_{t-1}+\frac{\kappa^{h}}{2}\left(\frac{h_{t}^{i}(j)}{h_{t-1}^{i}(j)}-1\right)^{2} h_{t}^{i}(j)= \\
=w_{t}^{i}(j) l_{t}^{i}(j)+q_{t}^{h} h_{t-1}^{i}(j)+p_{t} b_{t}^{i}(j)+V_{t}^{i}(j)
\end{gathered}
$$

Where $w_{t}^{i}$ is the nominal wage index and $i^{b i}$ the nominal interest rate on loans to impatient households. As the interest rate on loans is not indexed to inflation, Fisher's debt-inflation effects are present in the model. Similarly to the previous optimization, we assume that impatient households exhibit external habit formation, adjustment costs to changes of housing and experience similar shocks as patient households.

Impatient households seek to borrow as $\beta_{i}<\beta_{p}$. We assume a limited loan contract enforcement environment so that impatient households have to secure their loans with housing as collateral.

\footnotetext{
${ }^{12}$ Labor supply and wage setting of patient households is discussed in next section: Households wage setting and labor aggregation.
} 
The collateral constraint limits borrowing of impatient households up to a fraction of their expected housing wealth:

$$
\left(1+i_{t}^{b i}\right) b_{t}^{i}(j) p_{t} \leq m^{i} q_{t+1}^{h} h_{t}^{i}(j)
$$

Where $m^{i}$ is the maximum loan-to-value ratio set by banks and $q_{t+1}^{h}$ is an expected house price in time $t+1$. The collateral constraint is binding in steady state and shocks are considered to be small enough to keep the borrowing constraints always binding, as in Iacoviello (2005).

The first order conditions of the impatient household optimization problem consists of the budget and collateral constraints and following equations: ${ }^{13}$

$$
\begin{gathered}
\lambda_{t}^{i}(j)=\frac{1}{c_{t}^{i}(j)-\rho^{h} \bar{c}_{t-1}^{i}} \\
\frac{\eta^{h}}{h_{t}^{i}(j)}+\lambda_{t+1}^{i}(j) \beta_{i}\left[q_{t+1}^{h}+\kappa_{h}\left(\frac{h_{t+1}^{i}(j)}{h_{t}^{i}(j)}-1\right)\left(\frac{h_{t+1}^{i}(j)}{h_{t}^{i}(j)}\right)^{2}\right]+\mu_{t}^{i}(j) m^{i} q_{t+1}^{h}= \\
=\lambda_{t}^{i}(j)\left[q_{t}^{h}+\kappa_{h}\left(\frac{h_{t}^{i}(j)}{h_{t-1}^{i}(j)}-1\right) \frac{h_{t}^{i}(j)}{h_{t-1}^{i}(j)}+\frac{\kappa_{h}}{2}\left(\frac{h_{t}^{i}(j)}{h_{t-1}^{i}(j)}-1\right)^{2}\right] \\
\lambda_{t}^{i}(j)=\mu_{t}^{i}(j)\left(1+i_{t}^{b i}\right)+\lambda_{t+1}^{i}(j) \beta_{p}\left(1+i_{t}^{b i}\right)
\end{gathered}
$$

Where $\lambda_{t}^{i}$ and $\mu_{t}^{i}$ are Lagrange multipliers related to the budget and the collateral constraints. The index $j$ can be dropped as consumption, saving, and labor income adjusted by net labor subsidies are identical across impatient households.

\section{Households wage setting and labor aggregation}

Both impatient and patient households supply differentiated types of labor to competitive employment intermediaries. These intermediaries bundle different kinds of labor into homogenous labor bundles using CES aggregation and minimizing costs given agents' wages and total demand for homogenous bundles:

$$
\int_{0}^{1} w_{t}^{s}(j) l_{t}^{s}(j) \underset{l_{t}^{S}(j)}{\longrightarrow} \min
$$

s.t.

$$
l_{t}^{S}=\left[\int_{0}^{1} l_{t}^{S}(j)^{\frac{\epsilon-1}{\epsilon}} d j\right]^{\frac{\epsilon}{1-\epsilon}}
$$

\footnotetext{
${ }^{13}$ Labor supply and wage setting of impatient households is discussed in subsection: Households wage setting and labor aggregation.
} 
Where $s \in\{p, i\}, \epsilon$ is the elasticity of substitution between differentiated types of labor and $l_{t}^{s}$ is given aggregate demand for the $s$-bundle of labor. The aggregation is assumed to be costless.

The optimization problem of labor bundlers leads to demand functions for labor of $j$-th household:

$$
l_{t}^{S}(j)=\left(\frac{w_{t}^{S}(j)}{w_{t}^{S}}\right)^{-\epsilon} l_{t}^{S}
$$

Households are constrained in their opportunity to re-optimize their wage contracts assuming Calvo's pricing. In particular, each period they face a state-invariant probability of $\left(1-\xi_{w}\right)$ to update their wages. In the absence of a signal to re-negotiate, however, wages are adjusted by the overall wage inflation for each group of households. Adjusting the household optimization problems by a limited opportunity to re-optimize wage contracts and imposing the labor demand constraints, a derivative with respect to $w_{t}^{S}(j)$ leads to a wage version of Phillips curve (PC). The optimal real wage set by households is equal to the marginal rate of substitution of consumption for leisure adjusted by wage markups. ${ }^{14}$ The log-linear version of wage PC is:

$$
\Delta w_{t}^{S}=\frac{1}{1+\beta_{s}} \Delta w_{t-1}^{S}+\frac{\beta_{s}}{1+\beta_{s}} \Delta w_{t+1}^{S}+\frac{\left(1-\xi_{w}\right)\left(1-\xi_{w} \beta_{s}\right)}{\xi_{w}\left(1+\beta_{s}\right)} \ln \left(\frac{\operatorname{Markup}_{w}\left(c_{t}^{S}-\rho^{h} c_{t-1}^{S}\right) p_{t}}{w_{t}^{S}}\right)
$$

Where $\Delta w_{t}^{s}$ is a growth rate of nominal wage.

Two types of homogenous labor are aggregated by additional layer of fully competitive labor aggregators and supply to entrepreneurs. Similarly to the previous optimization problem, these aggregators seek to minimize costs of a homogenous labor bundle given aggregate demand for labor by entrepreneurs $l_{t}^{e}$ and wages $w_{t}^{i}, w_{t}^{p}$ :

$$
w_{t}^{p} l_{t}^{p}+w_{t}^{i} l_{t}^{i} \underset{l_{t}^{i}, l_{t}^{p}}{\longrightarrow} \min
$$

s.t.

$$
l_{t}^{e}=\left(l_{t}^{p}\right)^{\gamma}\left(l_{t}^{i}\right)^{1-\gamma}
$$

The optimization problem of aggregators generates demand equations for $l_{t}^{p}$ and $l_{t}^{s}$.

\section{Entrepreneurs}

Entrepreneurs own intermediate production firms. Introducing entrepreneurs along with impatient households helps to capture the credit cycle. Entrepreneurs are impatient and use loans to financing current consumption and capital investment. Their borrowing is secured using

${ }^{14}$ See, e.g. Erceg et al. (1999). 
productive capital as collateral. All productive capital has to be used in the economy; additional capital can be accumulated via investment and it can decrease only by depreciation.

A representative entrepreneur consumes final goods $c_{t}^{e}$, demands capital $k_{t}^{e}$ and labor $l_{t}^{e}$ to produce intermediate goods $y_{t}$; and takes loans from banks $b_{t}^{e}$ to finance its expenditures. The $j$ th entrepreneur strives to maximize its discounted utility:

$$
E_{0} \sum_{t=0}^{\infty} \beta_{e}^{t}\left[\ln \left(c_{t}^{e}(j)-\rho^{h} \bar{c}_{t-1}^{e}\right)\right] \underset{c_{t}^{e}(j), k_{t}^{e}(j), l_{t}^{e}(j), b_{t}^{b e}(j)}{\longrightarrow} \max
$$

subject to a production function:

$$
y_{t}(j)=a_{t}\left(k_{t-1}^{e}(j)\right)^{1-\alpha}\left(l_{t}^{e}(j)\right)^{\alpha}
$$

and a budget constraint:

$$
\begin{array}{r}
p_{t} c_{t}^{e}(j)+w_{t} l_{t}^{e}(j)+q_{t}^{k} k_{t}^{e}(j)+\left(1+i_{t-1}^{b e}\right) b_{t-1}^{b e}(j) p_{t-1}= \\
=p_{t}^{w} y_{t}(j)+q_{t}^{k}(1-\delta) k_{t-1}^{e}(j)+p_{t} b_{t}^{e}(j)
\end{array}
$$

Where $q_{t}^{k}$ is the price of capital, $w_{t}$ is the wage paid for homogenous labor by the entrepreneur, $i_{t}^{b e}$ is the interest rate on loans to entrepreneurs, $\delta$ is the depreciation rate on physical capital and $p_{t}^{w}$ is the price of intermediate production. The term $a_{t}$ is a TFP productivity term following an autoregressive process subject to productivity shocks. The interest rate on loans is not indexed to inflation and therefore an unexpected increase of prices transfers real wealth from lenders to borrowers. Capital enters the production process with a lag of one period. This time-to-built feature helps to match empirical correlations of real variables within the business cycle.

Entrepreneurs borrow as $\beta_{e}<\beta_{p}$ facing a collateral constraint on loans:

$$
\left(1+i_{t}^{b e}\right) b_{t}^{e}(j) p_{t} \leq m^{e} q_{t+1}^{k} k_{t}^{e}(j)
$$

Where $q_{t+1}^{k}$ is expected price of capital in time $t+1$.

The first order conditions of the optimization problem above are as follows:

$$
\begin{gathered}
\lambda_{t}^{e}(j)=\frac{1}{c_{t}^{e}(j)-\rho^{h} \bar{c}_{t-1}^{e}} \\
\frac{w_{t}}{p_{t}^{w}}=\frac{\alpha y_{t}(j)}{l_{t}^{e}(j)} \\
\lambda_{t}^{e}(j) q_{t}^{k}=\lambda_{t+1}^{e}(j) \beta_{e}\left[\frac{p_{t+1}^{w}(1-\alpha) y_{t+1}}{k_{t}^{e}(j)}+q_{t+1}^{k}(1-\delta)\right]+\mu_{t}^{e}(j) m^{e} q_{t+1}^{k}(1-\delta) \\
\lambda_{t+1}^{e}(j) \beta_{e}\left(1+i_{t}^{b e}\right)+\mu_{t}^{e}(j)\left(1+i_{t}^{b e}\right)=\lambda_{t}^{e}(j)
\end{gathered}
$$


Where $\lambda_{t}^{e}$ and $\mu_{t}^{e}$ are Lagrange multipliers related to the budget and collateral constraints of entrepreneurs.

\section{Capital producers}

Fully competitive capital producers buy depreciated capital $k_{t-1}^{e}$ at the beginning of time $t$ from entrepreneurs and combine it with newly accumulated capital. Final goods are used to create new capital. Capital producers are owned by entrepreneurs and face the following optimization problem subject to a capital accumulation equation:

$$
E_{0} \sum_{t=0}^{\infty} \Xi_{0, t}^{e}\left[q_{t}^{k} k_{t}^{e}-q_{t}^{k}(1-\delta) k_{t-1}^{e}-p_{t} j_{t}\right] \underset{k_{t, j}^{e}}{\longrightarrow} \max
$$

s.t.

$$
k_{t}^{e}=(1-\delta) k_{t-1}^{e}+\left[1-\frac{\kappa^{j}}{2}\left(\frac{j_{t}}{j_{t-1}}-1\right)^{2}\right] j_{t}
$$

Real investment in final goods needed to create new capital is labeled as $j_{t}$ and $\Xi^{e}$ denotes the pricing kernel of entrepreneurs. Capital producers experience adjustment costs on their investment whenever they change the speed of capital accumulation.

The first order conditions of the optimization problem consist of the capital accumulation equation and:

$$
q_{t}^{k}+\frac{\lambda_{t+1}^{e}}{\lambda_{t}^{e}} q_{t+1}^{k} \kappa^{j}\left(\frac{j_{t+1}}{j_{t}}-1\right)\left(\frac{j_{t+1}}{j_{t}}\right)^{2}=\frac{q_{t}^{k} \kappa^{j}}{2}\left(\frac{j_{t}}{j_{t-1}}-1\right)^{2}+q_{t}^{k} \kappa^{j}\left(\frac{j_{t}}{j_{t-1}}-1\right) \frac{j_{t}}{j_{t-1}}+p_{t}
$$




\section{Final goods producers and aggregators}

The intermediate product is used to create final goods which are either consumed or invested. The final goods producers are monopolistically competitive firms with staggered price setting of the Calvo type. The production function is linear, simply transforming intermediate production to final goods $\bar{y}_{t}(f)=y_{t}(f)$, where $y_{t}(f)$ is demand for intermediate product by the $f$-th firm producing final goods.

The final goods producer, $f$, maximizes profit, choosing price $p_{t}(f)$ and demand for intermediate goods, with a limited stochastic opportunity, $\left(1-\xi_{p}\right)$, to optimize price contracts and a demand for his final goods $\bar{y}_{t}(f)$.

$$
E_{0} \sum_{t=0}^{\infty} \xi_{p}^{t} \Xi_{0, t}^{p}\left[p_{t}(f) \bar{y}_{t}(f)-p_{t}^{w} y_{t}(f)\right] \underset{p_{t}(f), y_{t}(f)}{\longrightarrow} \max
$$

s.t.

$$
\bar{y}_{t}(f)=\left(\frac{p_{t}(f)}{p_{t}}\right)^{-\frac{1+\epsilon^{p}}{\epsilon^{p}}} \bar{y}_{t}
$$

Final goods producers who cannot re-optimize use full backward indexation to overall price inflation. The linear version of the first order conditions for this optimization problem consists of the standard Phillips curve which is partially forward looking. Optimal flexible prices are set as a markup over production costs equal to $p^{w}$ :

$$
\Delta p_{t}=\frac{1}{1+\beta_{p}} \Delta p_{t-1}+\frac{\beta_{p}}{1+\beta_{p}} \Delta \mathrm{p}_{\mathrm{t}+1}+\frac{\left(1-\xi_{p}\right)\left(1-\xi_{p} \beta_{p}\right)}{\xi_{p}\left(1+\beta_{p}\right)} \ln \left(\frac{\operatorname{Markup}_{p} p_{t}^{w}}{p_{t}}\right)+\epsilon_{t}^{p}
$$

The output of final goods producers is collected by fully competitive distributors. These distributors aggregate different types of final product and sell it as homogenous goods. As these goods can be used for consumption or investment purposes, the following identity holds:

$$
\bar{y}_{t}=y_{t}=c_{t}+j_{t}
$$

Where $c_{t}$ is overall consum ption defined as $c_{t}=c_{t}^{e}+c_{t}^{p}+c_{t}^{i}+c_{t}^{g} \mathrm{w}$ ith $c_{t}^{g}$ as governm ent consumption.

The demand function for final goods $\bar{y}_{t}(f)$ is derived from the optimization problem of distributors. Distributors split the total amount of demand for consumption and investment goods, $y_{t}$, among final goods producers, given their prices $p_{t}(f)$. They seek to minimize total costs: 


$$
\int_{0}^{1} p_{t}(f) \bar{y}_{t}(f) d f \underset{\bar{y}_{t}(f)}{\longrightarrow} \min
$$

s.t.

$$
\bar{y}_{t}=\left(\int_{0}^{1} \bar{y}_{t}(f)^{\frac{1}{1+\epsilon^{p}}} d f\right)^{1+\epsilon^{p}}
$$

Where $\epsilon^{p}$ determines the price elasticity of substitution among types of goods.

\section{Banks}

Credit in the model economy is extended via financial intermediaries - banks. The design of the banking sector resembles Gerali et al. (2010), but extends the setup to include liquidity requirements. Banks grant loans using households' deposits and their own capital and face capital and liquidity requirements. Two layers of banks - wholesale banks and retail branchesare assumed in order to facilitate the derivation of the model. These two types of banks can be merged into one which is a model counterpart of real banks.

A representative wholesale bank collects deposits, $d_{t}$, from patient agents, accumulates banking capital, $k_{t}^{b}$, and provides loans, $b_{t}^{b}$, to impatient households and entrepreneurs through retail branches. A wholesale bank faces the following optimization problem:

$$
\begin{aligned}
E_{0} \sum_{t=0}^{\infty} \Xi_{0, t}^{p}\left[p_{t} d_{t}+p_{t} k_{t}^{b}-p_{t} b_{t}+\left(1+i_{t-1}^{b}\right)\left(1-\eta_{t}\right) b_{t-1} p_{t-1}+\left(1+i_{t-1}\right) \eta_{t} b_{t-1} p_{t-1}\right. \\
\left.\quad-\left(1+i_{t-1}\right) d_{t-1} p_{t-1}-k_{t-1}^{b} p_{t-1}-\frac{\kappa^{b}}{2}\left(\frac{k_{t-1}^{b}}{w_{t-1}^{a} b_{t-1}}-v^{b}\right)^{2} k_{t-1}^{b} p_{t-1}\right] \underset{d_{t}, b_{t}}{\longrightarrow} \max
\end{aligned}
$$

s.t.

$$
b_{t}=d_{t}+k_{t}^{b}
$$

Where $\Xi_{0, t}^{p}$ is the pricing kernel of patient households (owners of all banks), $b_{t}$, is the bank's assets, $i_{t}^{b}$ is an interest rate on wholesale loans and $i_{t}$ is a policy (interbank) rate.

The first order conditions of the problem encompass the financing identity and the equation:

$$
\left(1+i_{t}^{b}\right)=\left(1+i_{t}\right)-\kappa^{b}\left(\frac{k_{t}^{b}}{w_{t}^{a} b_{t}}-v^{b}\right)\left(\frac{k_{t}^{b}}{w_{t}^{a} b_{t}}\right)^{2}
$$

The wholesale bank's assets $b_{t}$ are divided between a common risky portfolio provided to retail banks for private sector loans $b_{t}^{b}=\left(1-\eta_{t}\right) b_{t}=b_{t}^{p}+b_{t}^{i}$; and a highly liquid portfolio. The highly liquid portfolio consists of government bonds which are rated as risk-free for regulatory purposes and bear the interbank interest rate. The share of liquid and risky assets in bank 
portfolios is determined by $\eta_{t}$ which is set by a regulatory authority. As the model focuses on macro-financial linkages, the fiscal side of the model is kept very simple and stylized. Therefore, we assume that supply of government bonds is infinite and that wholesale banks can obtain any amount needed at a given price.

Besides liquidity restrictions, wholesale banks face capital requirements. The capital requirement is defined with respect to risk-weighted assets. The risk weight $w_{t}^{a}$ measures the overall riskiness including government bonds. It implies that the liquidity requirements might interact with capital measures. A rise in the share of risk-free government bonds raises the liquidity ratio, and also raises the capital adequacy ratio by lowering risk-weighted assets. Banks face a quadratic penalty lowering their revenues in the event that their capital ratios differ from the required capital ratio. ${ }^{15}$ Whenever a shock lowers the share of capital below the required level, banks have to accumulate extra capital via retained earnings. To generate additional profits, banks raise the wholesale rate $i_{t}^{b}$.

All profits in the banking sector including wholesale banks as well as retail banks are collected and used either to pay dividends to patient households or to accumulate capital. The real profits of banking industry are:

$$
\begin{aligned}
\Pi_{t+1}^{b}=\left(1+i_{t}^{b i}\right) & b_{t}^{i}+\left(1+i_{t}^{b e}\right) b_{t}^{e} \\
& +\left(1+i_{t}\right) \eta_{t} b_{t}-\left(1+i_{t}^{d}\right) d_{t}-k_{t}^{b}-\frac{\kappa^{b}}{2}\left(\frac{k_{t-1}^{b}}{w_{t-1}^{a} b_{t-1}}-v^{b}\right)^{2} k_{t-1}^{b}
\end{aligned}
$$

In the model we assume that only a constant fraction $\omega$ of bank profits can be used to accumulate capital. The remaining fraction $(1-\omega)$ is used to make dividend payments to households. The constant dividend payout ratio constraints banks' ability to accumulate additional capital; it makes the accumulation costly and helps to capture frictions in equity markets. This assumption also simplifies the derivation of the model, allowing calibration of a dividend payout ratio. Bank capital behaves according to:

$$
k_{t}^{b}=\left(1-\delta^{b}\right) k_{t-1}^{b}+\frac{p_{t-1}}{p_{t}} \omega \Pi_{t-1}^{b}
$$

Where $\delta^{b}$ is the depreciation rate of bank capital. The non-zero depreciation rate anchors the share of bank capital to loans and might be considered as operating costs of capital in the banking sector.

Regulatory requirements on capital and costly capital accumulation induce an interaction between bank balance sheets and the transmission of monetary policy - the bank capital channel. In the event of an adverse shock to their capital adequacy positions, banks have to raise interest

\footnotetext{
${ }^{15}$ The quadratic penalty function fines both undershooting and over shooting of capital requirements. This can be viewed as a bank objective to maintain a constant capital buffer above the regulatory requirement.
} 
rates to generate extra profits. The widening of interest spreads will have contractionary effects on consumption and investment, analogous to a tightening of the stance of monetary policy. Similarly, liquidity requirements affect bank profits and therefore alter the transmission of monetary policy.

Loans and deposits are extended via monopolistically competitive bank branches - retailers. Retail banks buy wholesale banks' assets $b^{b}$ and use them to provide loans. Retail banks pay the nominal interest rate $i^{b}$ for assets of wholesale banks and then on-lend with markups above this rate. Following Benes and Lees (2007) we assume that retail banks face a low probability to reoptimize $\left(1-\xi_{n}\right)$ where $n \in\{i, e\}$ refers to two groups of retail banks providing loans either to households or to entrepreneurs. The distinction between the interest rate on loans to households and to entrepreneurs facilitates capturing the observed spreads and the maturity structure of lending.

Individual retail banks face the optimization problem:

$$
E_{0} \sum_{t=0}^{\infty} \Xi_{0, t}^{p} \xi_{n}^{t}\left[\left(1+i_{t}^{b n}(j)\right) b_{t}^{n}(j) p_{t}-\left(1+i_{t}^{b}\right) b_{t}^{n}(j) p_{t}\right]_{i_{t}^{b n}} \max
$$

s.t.

$$
b_{t}^{n}(j)=\left(\frac{1+i_{t}^{b n}(j)}{1+i_{t}^{b n}}\right)^{\frac{\vartheta}{1-\vartheta}} b_{t}^{n}
$$

Where the demand function for loans by the $j$-th bank $b_{t}^{n}(j)$ is derived from an optimization problem of distributors who split the total demand for loans among retail banks. Distributors of loans are assumed to be fully competitive, collecting differentiated credit contracts from monopolistic retail banks and producing homogenous loans. Given demand for loans and interest rates they seek to minimize costs - the interest rate paid on homogenous loans.

An equation for the interest rate on loans resembling the standard Phillips curve is an outcome of this optimization.

$$
\mathrm{i}_{\mathrm{t}}^{b n}=\frac{1}{1+\beta_{p}} \mathrm{i}_{\mathrm{t}-1}^{b n}+\frac{\beta_{p}}{1+\beta_{p}} \mathrm{i}_{\mathrm{t}+1}^{b n}+\frac{\left(1-\xi_{n}\right)\left(1-\xi_{n} \beta_{p}\right)}{\xi_{n}\left(1+\beta_{p}\right)}\left(i_{t}^{b}+\operatorname{markup}^{b n}-i_{t}^{b n}\right)
$$

Deposit retail banks are assumed to collect deposits from households and pass them to wholesale banks. ${ }^{16}$ Similarly to the retail banks extending loans they have monopolistic power to set interest rates. Deposit banks adjust their interest rate according to the interbank (policy) interest rate, taking into account a low probability to re-optimize. Assuming that lending rates are stickier than

\footnotetext{
${ }^{16}$ In facts differentiated deposit contracts are collected by distributors and offered to wholesale banks as homogenous deposits.
} 
deposit rates helps to match the effects of maturity transformation on bank profits, since deposits typically have shorter maturity, and more flexible rates, than loans

\section{Monetary policy}

Monetary policy is assumed to follow a common Taylor type rule of the form:

$$
i_{t}=\phi_{i} i_{t-1}+\left(1-\phi_{i}\right)\left(\bar{r}+\Delta p_{t}+\phi_{p}\left(\Delta p_{t}-\pi^{\text {target }}\right)\right)
$$

Where $\bar{r}$ is the real policy neutral $\operatorname{rate}^{17}, \Delta p_{t}$ is the rate of inflation of consumer prices, $\pi^{\text {target }}$ is the inflation target. ${ }^{18}$ Parameters $\phi_{i}$ and $\phi_{p}$ determine the persistence and the aggressiveness of monetary policy.

\section{Government}

The government is assumed to adjust its spending $c_{t}^{g}$ to keep a stable proportion relative to nominal consumption of patient households - pcg2pcp.

$$
\frac{p_{t} c_{t}^{g}}{p_{t} c_{t}^{p}}=p c g 2 p c p
$$

Government consumption is financed via lump-sum taxes and bonds. The budget constraint is:

$$
p_{t} c_{t}^{g}+p_{t-1} \eta_{t-1} b_{t-1}\left(1+i_{t-1}\right)=p_{t} \eta_{t} b_{t}+\Gamma_{t}
$$

\section{B. Steady-state and Solution of the Model}

The optimality conditions of the problems listed in the previous section constitute the model equations which take the form of a non-linear system of expectational difference equations. The model is linearized around the non-stochastic steady state and then solved for rational expectation equilibrium. The linearization, rational expectations solution, and simulations are conducted using the IRIS Toolbox. ${ }^{19}$

The non-stochastic steady state of the $\mathrm{m}$ odel is derived by setting all shocks to their $\mathrm{m}$ eanszeros - and solving the non-lin ear system analytically. ${ }^{20}$ The system of steady-state equations is

\footnotetext{
${ }^{17}$ The real policy neutral rate equals to the natural logarithm of the inverted deterministic discount factor of patient households adjusted by margins on the deposit rate.

${ }^{18}$ The output gap is not considered in the policy rule.

${ }^{19}$ See www.iris-tolbox.com.

${ }^{20}$ An analytical expression of model steady state is found using the Symbolic Math Toolbox in Matlab.
} 
reshuffled and divided into separate but sequentia 1 blocks which can be so lved more easily. In the solution, the price of final consumption goods, the supply of housing, and productivity are used as numeraires. Following the model structure, steady state is the s ame as if prices, wages, and lending and deposit rates were fully flexible and banks met regulatory requirements.

The analytical solution of model steady state h elps to calibrate model parameters. Inverting the computation, steady state parameters can be expressed as function of observed great ratios.

\section{Model Calibration}

Following common calibration procedures we distinguish between parameters determining steady state and parameters affecting only the dynamics of the model.

The steady-state parameters are listed in Table 13. They were calibrated to meet the observed great ratios. We set the deterministic discount factor of patient households at 0.9925 to match the observed levels of deposit rates. Discount factors of impatient households and entrepreneurs are set equal to 0.965 which is similar to Iacoviello (2005). Discount rates together with parameters of the banking sector are set to match the observed ratios of loans to real output. ${ }^{21}$

The housing scaling factor is set at 1 and, together with the weight of housing in household utility, pins down housing wealth and the relative price of housing. In order to achieve plausible levels of these variables $\eta^{h}$ is set at 0.15 , which implies that a ratio of housing wealth to GDP of around 2.4 in both economies..

The habit persistence coefficient is set equal to 0.5 which is in the range commonly used in the literature.

The share of labor in value added is set equal to 0.7 in the EA and to 0.65 in the United States. The lower share in the United States reflects a higher capital endowment. The depreciation rate of capital is slightly above values commonly recommended in the literature reaching 26 percent per annum in the EA and 16 percent per annum in the United States. However, these values are consistent with observed ratios of nominal investment to output.

The share of patient households is calibrated to 0.8 in the EA and 0.75 in the United States.

\footnotetext{
${ }^{21}$ Bank assets reached about 100 percent of GDP in the U.S. and more than 150 percent in Euro Area in 2009. Approximately half of bank assets are loans.
} 
Table 13. Calibration of Model's Parameters Affecting Steady-state

\begin{tabular}{|c|c|c|c|}
\hline \multirow{2}{*}{ Parameter } & \multirow{2}{*}{ Description } & \multicolumn{2}{|c|}{ Calibration } \\
\hline & & EA & U.S. \\
\hline \multicolumn{4}{|c|}{ Households and entrepreneurs } \\
\hline$\beta_{p}$ & $\begin{array}{l}\text { Deterministic discount factor-patient } \\
\text { households }\end{array}$ & 0.9925 & 0.9925 \\
\hline$\beta_{i}$ & $\begin{array}{l}\text { Deterministic discount factor-impatient } \\
\text { households }\end{array}$ & 0.965 & 0.965 \\
\hline$\beta_{e}$ & Deterministic discount factor-entrepreneurs & 0.965 & 0.965 \\
\hline$\eta^{h}$ & Scaling factor of housing in household utility & 0.15 & 0.15 \\
\hline $\bar{h}$ & Housing scaling & 1 & 1 \\
\hline$\rho^{h}$ & Habit persistence & 0.5 & 0.5 \\
\hline \multicolumn{4}{|l|}{ Production } \\
\hline$\alpha$ & Share of labor in added value & 0.7 & 0.65 \\
\hline$\gamma$ & Share of patient households & 0.8 & 0.75 \\
\hline$\delta$ & Depreciation rate of physical capital & 0.065 & 0.04 \\
\hline \multicolumn{4}{|c|}{ Collateral and banking } \\
\hline$m^{e}$ & Loan-to-value ratio-entrepreneurs & 0.4 & 0.24 \\
\hline$m^{i}$ & Loan-to-value ratio_impatient households & 0.65 & 0.7 \\
\hline$\eta$ & Share of liquid portfolio in assets & 0.3 & 0.3 \\
\hline$v^{b}$ & Capital adequacy ratio & 0.08 & 0.08 \\
\hline $1-\omega$ & Dividend payout ratio & 0.23 & 0.42 \\
\hline$\delta^{b}$ & Depreciation rate of bank capital & 0.018 & 0.016 \\
\hline \multicolumn{4}{|c|}{ Interest rate margins } \\
\hline$i^{b i}-i$ & Margins on lending rates to households & $2 / 400$ & $2.5 / 400$ \\
\hline$i^{b e}-i$ & Margins on lending rates to entrepreneurs & $2 / 400$ & $2.5 / 400$ \\
\hline$i-i^{d}$ & Margins on deposit rates & 0 & $0.25 / 400$ \\
\hline \multicolumn{4}{|l|}{ Markups } \\
\hline$p / p^{y}$ & Price markup & 1.2 & 1.3 \\
\hline$w / w^{f l e x}$ & Wage markup & 1.3 & 1.2 \\
\hline
\end{tabular}

Source: Authors' calculations.

Calibration of the loan-to-value ratio for impatient households is set in line with the empirical findings of Calza et al. (2007) reaching 0.65 in the EA and 0.7 in the United States In the model loan-to-value ratios for entrepreneurs determine the share of loans to firms in total loans. The ratio is calibrated to 0.4 for the EA and 0.24 for the United States. The lower ratio in the United States case reflects firm financing which comparing to the EA relies more on equities.

Regulatory requirements are assumed to be equal in both economies. As the model solution is linear the particular choice of regulatory targets has negligible effects on the results of the simulations. The share of liquid assets in bank portfolios is set above observed ratios of cash and government bonds to bank assets as low risk bonds and equities are considered as liquid. The capital adequacy ratio is set to 8 percent. The dividend payout ratio is in line with observed data, and nearly twice as high in the United States as in the EA. The depreciation rate of bank capital 
is calibrated to match observed returns on bank equities. Interest rate margins are calibrated to replicate those observed in the data. The calibration of steady-state parameters implies ratios listed in Table 14.

Table 14. Implied Model Ratios

\begin{tabular}{lcc}
\hline Ratios/Returns & EA & U.S. \\
& In percent \\
\hline Private consumption to GDP & 62 & 65 \\
Government consumption to GDP & 20 & 20 \\
Investment to GDP & 18 & 15 \\
Productive capital to GDP & 68 & 95 \\
Housing wealth to GDP & 243 & 236 \\
Return on equity & 9.4 & 11.0 \\
Banks assets to GDP & 55 & 53 \\
Household loans to total loans & 35 & 42 \\
\hline
\end{tabular}

Source: Authors' calculations.

Parameters affecting dynamics of the model are shown in Table 15 and calibrated based on impulse responses of the model. Calibration of price and wage inertia is set within the range commonly considered in the literature presuming that wages are stickier than prices. The probability of adjusting interest rates on loans to households is kept relatively moderate as these loans consist largely of mortgages with long duration and fixed interest rates.

With regard to policy parameters we calibrate the persistency of monetary policy rules in both countries equal to 0.5 . Following estimates of monetary policy rules provided by Christiano et al. (2008) the weight on inflation deviations from target is higher in the United States.

To verify the calibration, impulse responses to shocks were performed and model moments, particularly correlations, checked with the observed data. These analyses are not presented due restrictions on the paper length. The calibration of the model is considered as one of the main sources of uncertainty and further steps are needed to check its relevance. 
Table 15. Calibration of Model Dynamic Parameters

\begin{tabular}{|c|c|c|c|}
\hline \multirow{2}{*}{ Parameter } & \multirow{2}{*}{ Description } & \multicolumn{2}{|c|}{ Calibration } \\
\hline & & EA & U.S. \\
\hline \multicolumn{4}{|c|}{ Adjustment costs } \\
\hline$\kappa^{h}$ & Adjustment costs-housing & 25 & 25 \\
\hline$\kappa^{j}$ & Adjustment costs-capital & 0.8 & 0.8 \\
\hline$\kappa^{b}$ & Penalty on deviations from capital adequacy ratio & 45 & 45 \\
\hline \multicolumn{4}{|c|}{ Calvo parameters } \\
\hline $1-\xi_{p}$ & Probability to re-optimize consumer prices & 0.3 & 0.3 \\
\hline $1-\xi_{w}$ & Probability to re-optimize wages & 0.2 & 0.2 \\
\hline $1-\xi_{i}$ & Probability to re-optimize interest rate on loans to households & 0.3 & 0.2 \\
\hline $1-\xi_{e}$ & Probability to re-optimize interest rate on loans to entrepreneurs & 0.8 & 0.8 \\
\hline $1-\xi_{d}$ & Probability to re-optimize interest rate on deposits & 0.6 & 0.8 \\
\hline \multicolumn{4}{|c|}{ Monetary policy } \\
\hline$\phi_{i}$ & Persistency & 0.5 & 0.5 \\
\hline$\phi_{p}$ & Weight on inflation deviations & 1.6 & 1.9 \\
\hline
\end{tabular}

Source: Authors' calculations.

Figure 2. The Euro Area_Increasing Retained Earning via Dividend Policy

(2 p.p. Increase in Capital Requirements over 2 Years)
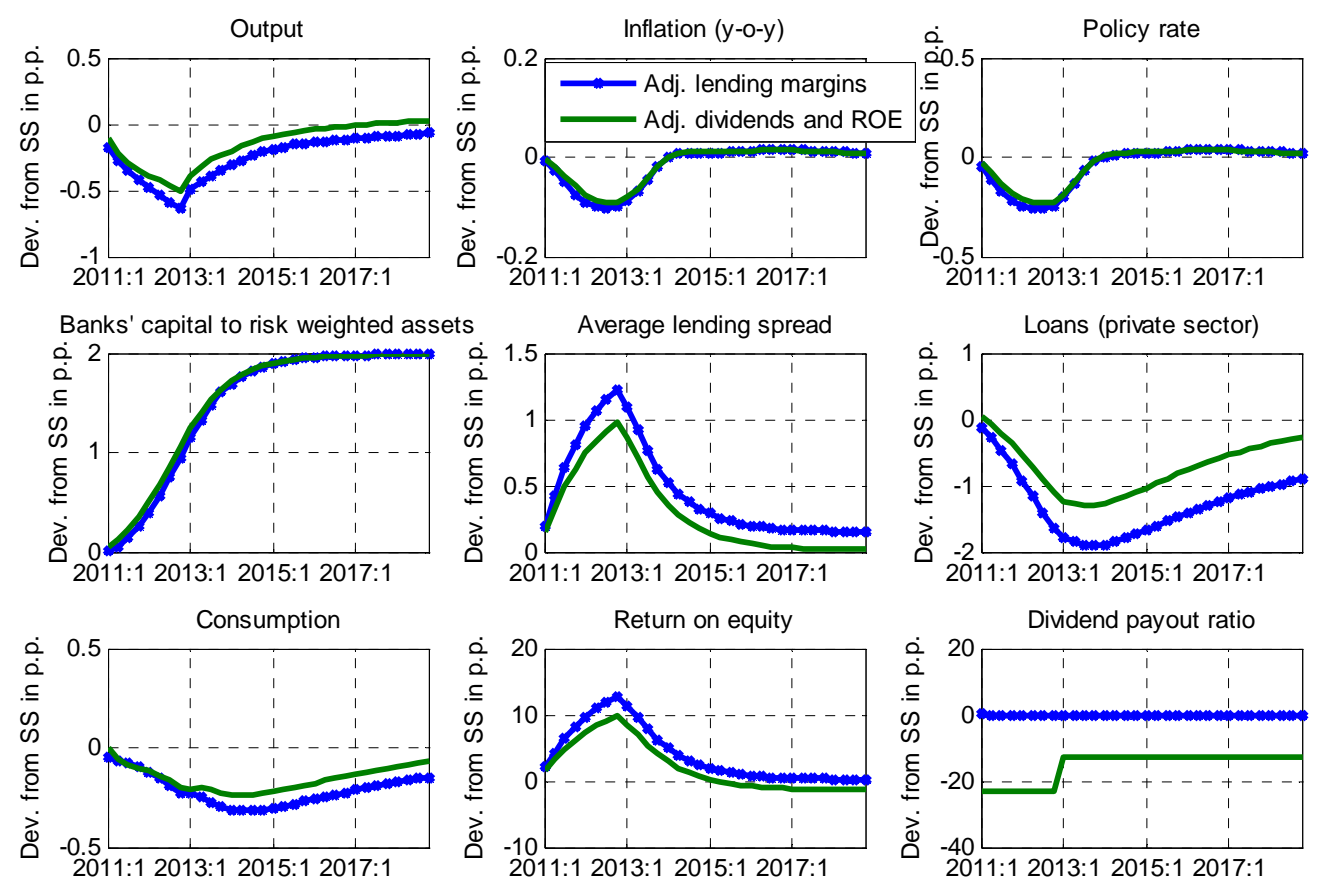

Source: Authors' calculations. 
Figure 3. The United States_Increasing Retained Earning via Dividend Policy

(2 p.p. Increase in Capital Requirements over 2 Years)
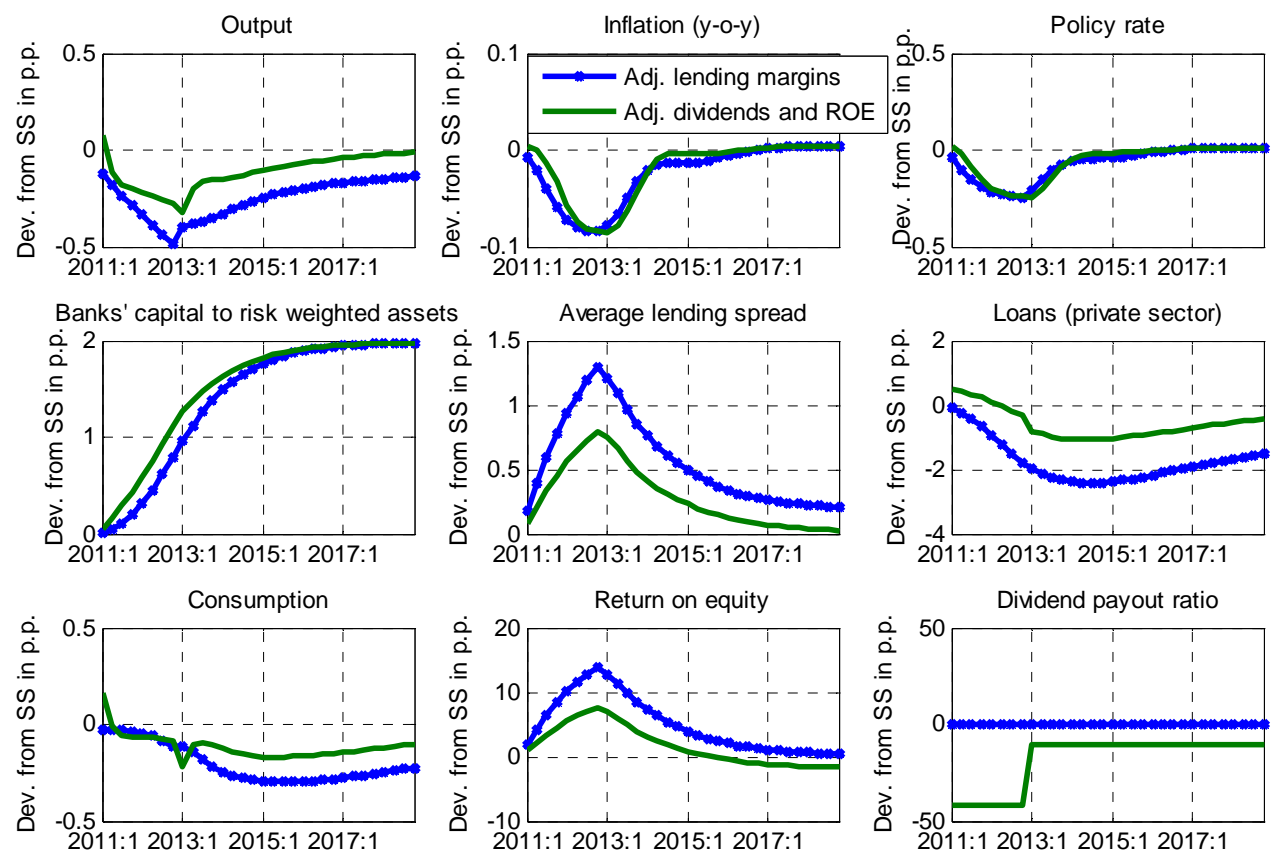

Source: Authors' calculations.

Figure 4. The Euro Area-Adjusting Banks Assets via the LTV Ratio (1 p.p. Decline of the LTV Ratio, No Change in Portfolio Riskiness)
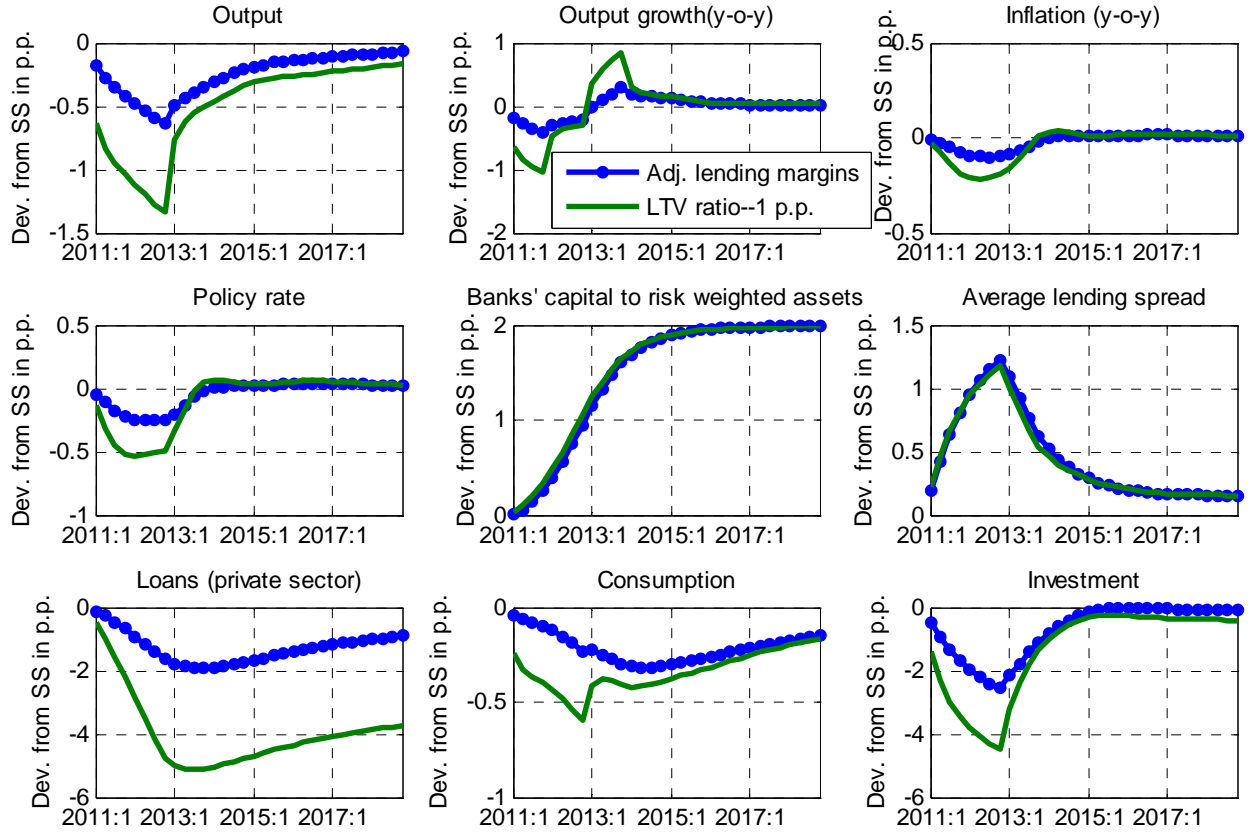

Source: Authors' calculations. 
Figure 5. The United States—Adjusting Banks Assets via the LTV Ratio

(1 p.p. Decline of the LTV Ratio, No Change in Portfolio Riskiness)
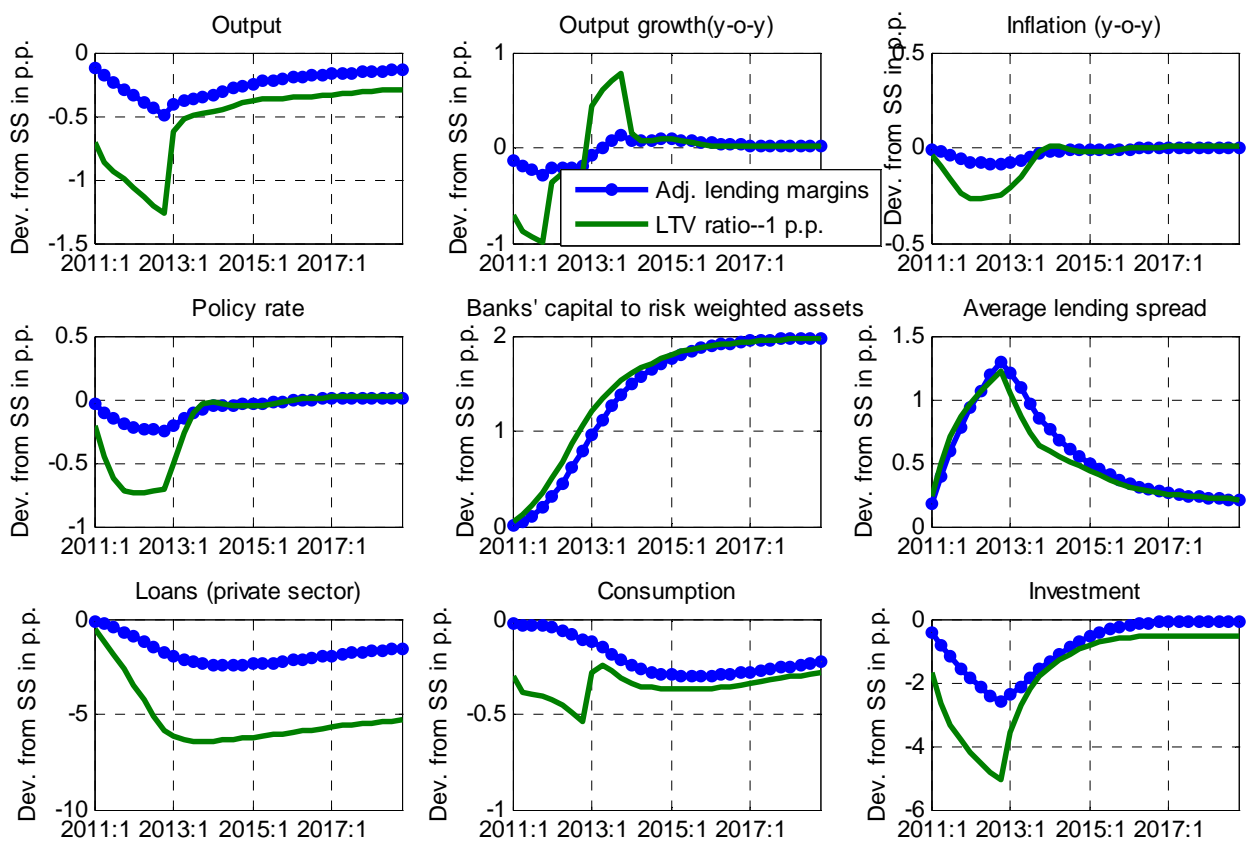

Source: Authors' calculations.

Figure 6. The Euro Area-Adjusting Banks Assets via the LTV Ratio and Portfolio Riskiness

(1 p.p. Decline of the LTV Ratio and 14 p.p. Decline of Asset Portfolio Riskiness)
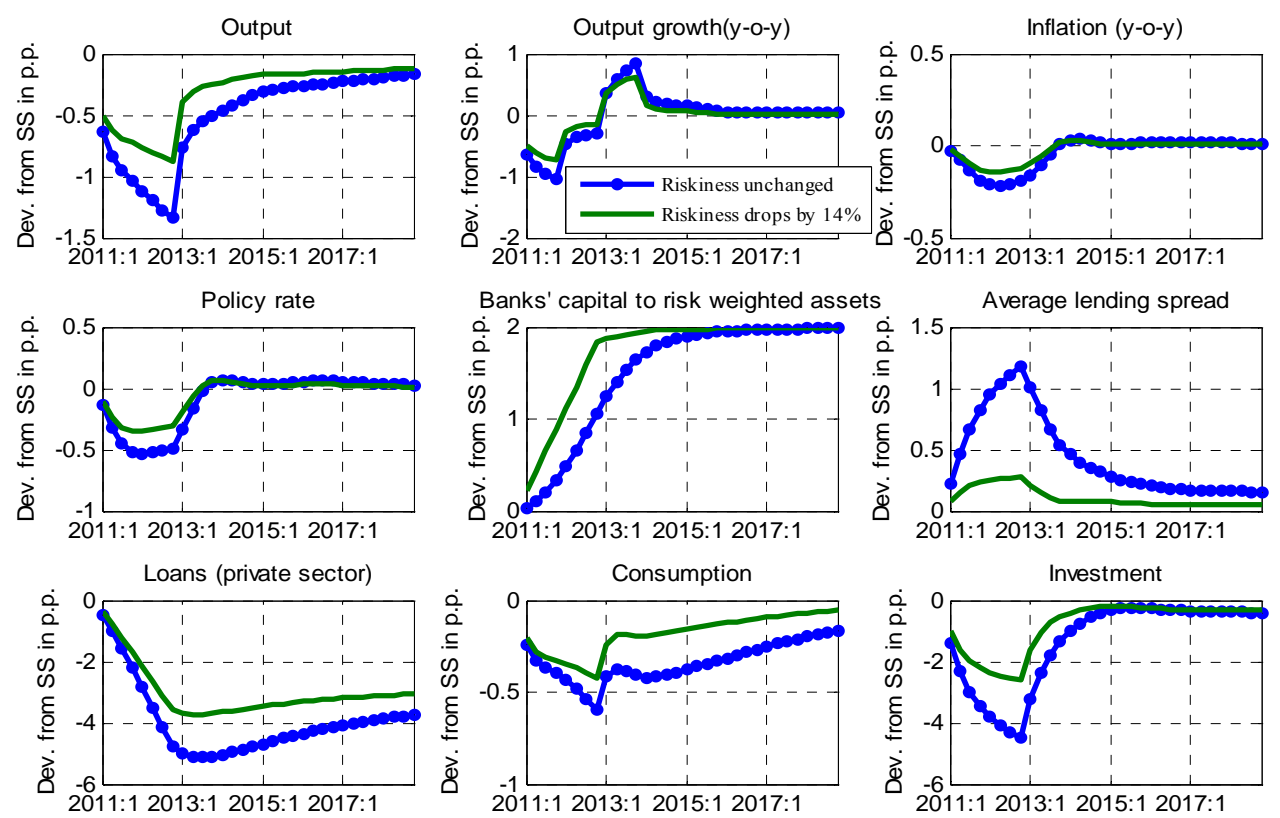

Source: Authors' calculations. 
Figure 7. The United States-Adjusting Banks Assets via the LTV Ratio and Portfolio Riskiness

(1 p.p. Decline of the LTV Ratio and 14 p.p. Decline of Asset Portfolio Riskiness)
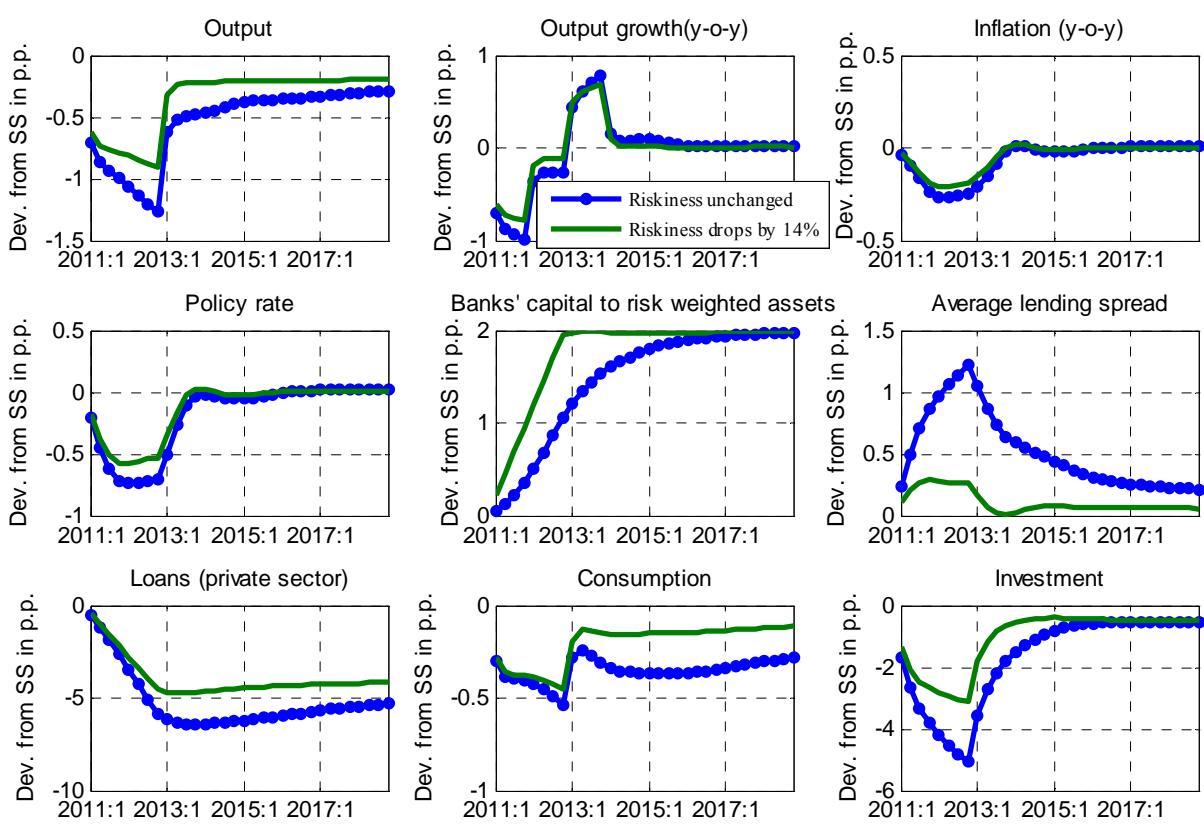

Source: Authors' calculations.

Figure 8. Effects of Tighter Liquidity Requirements

(25 p.p. Increase in Liquidity Requirements over 2 Years)
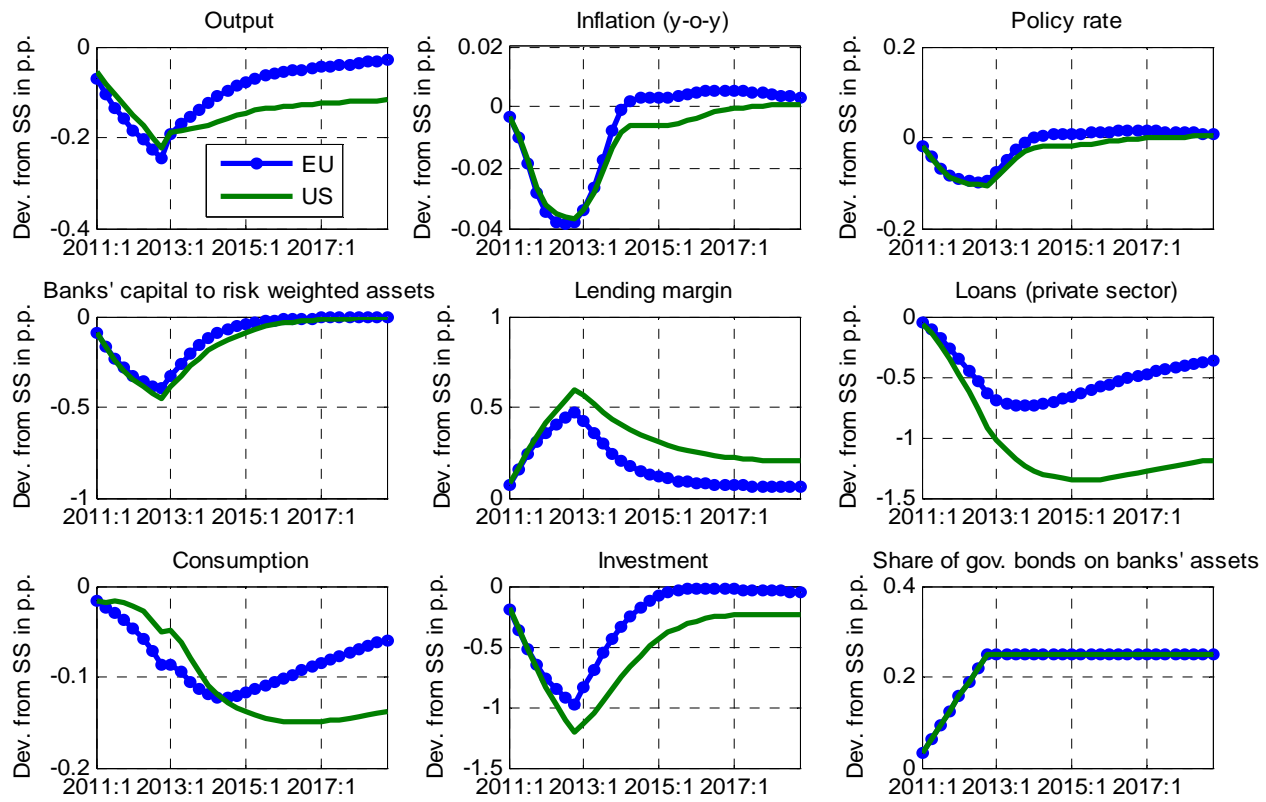

Source: Authors' calculations. 
Figure 9. The Euro Area—Effects of Tighter Liquidity Requirements under Different Risk-weighting Assumptions

(25 p.p. Increase in Liquidity Requirements over 2 Years)
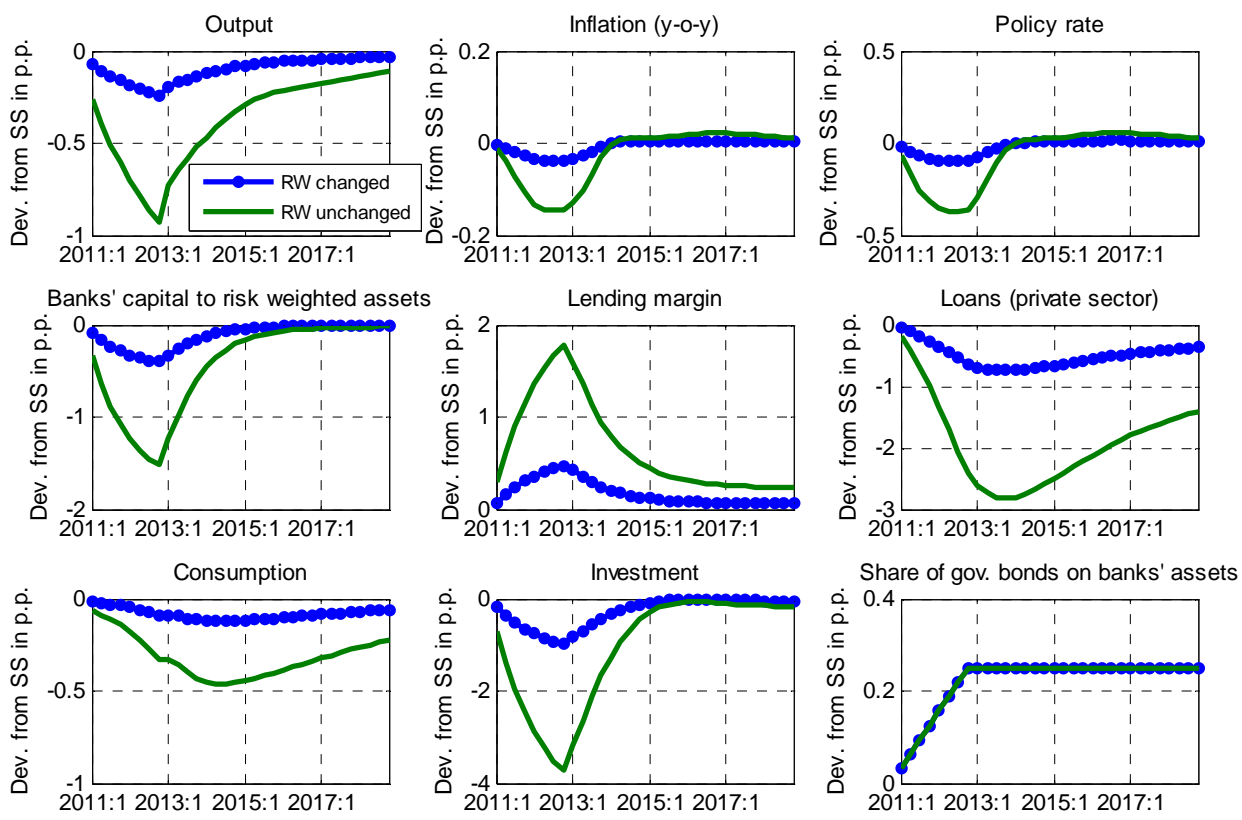

Source: Authors' calculations.

Figure 10. The United States-Effects of Tighter Liquidity Requirements under Different Risk-weighting Assumptions

(25 p.p. Increase in Liquidity Requirements over 2 Years)
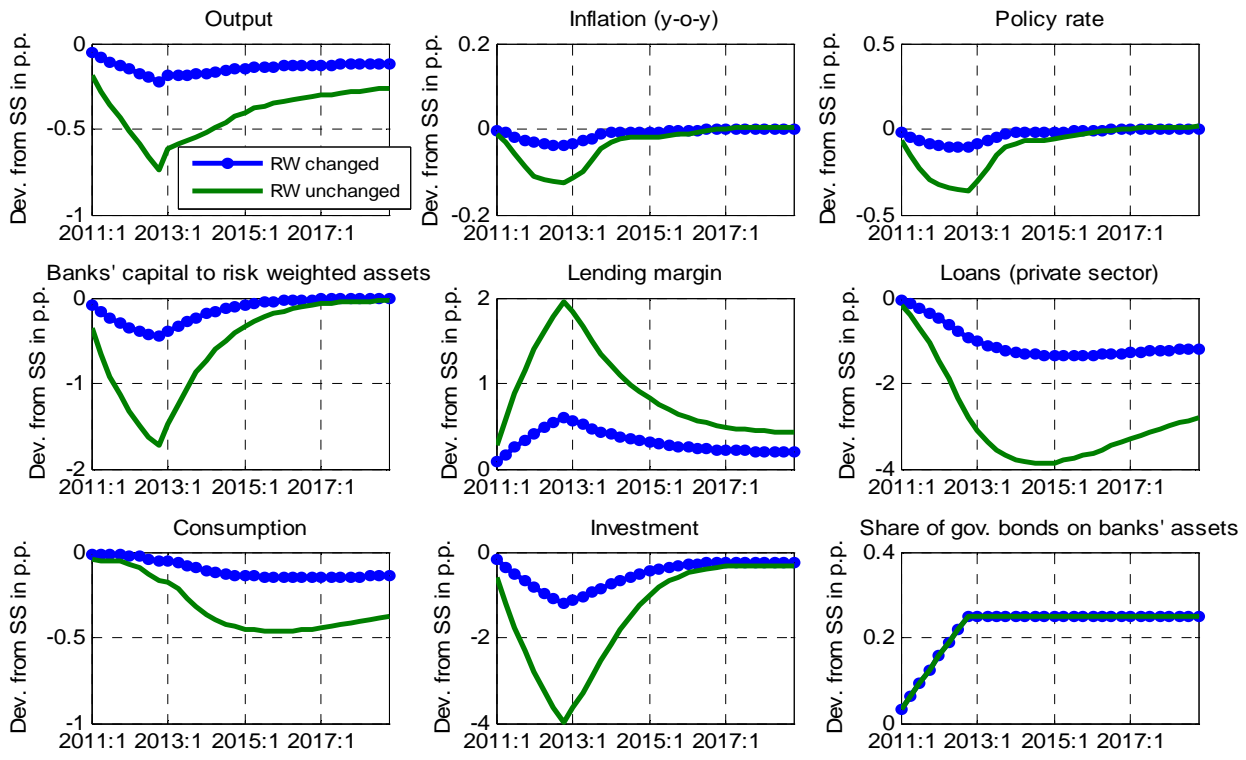

Source: Authors' calculations. 
Figure 11. The Euro Area-Effects of Tighter Capital Requirements over Different Horizons

(2 p.p. Increase in Capital Requirements, Increasing Lending Margins)
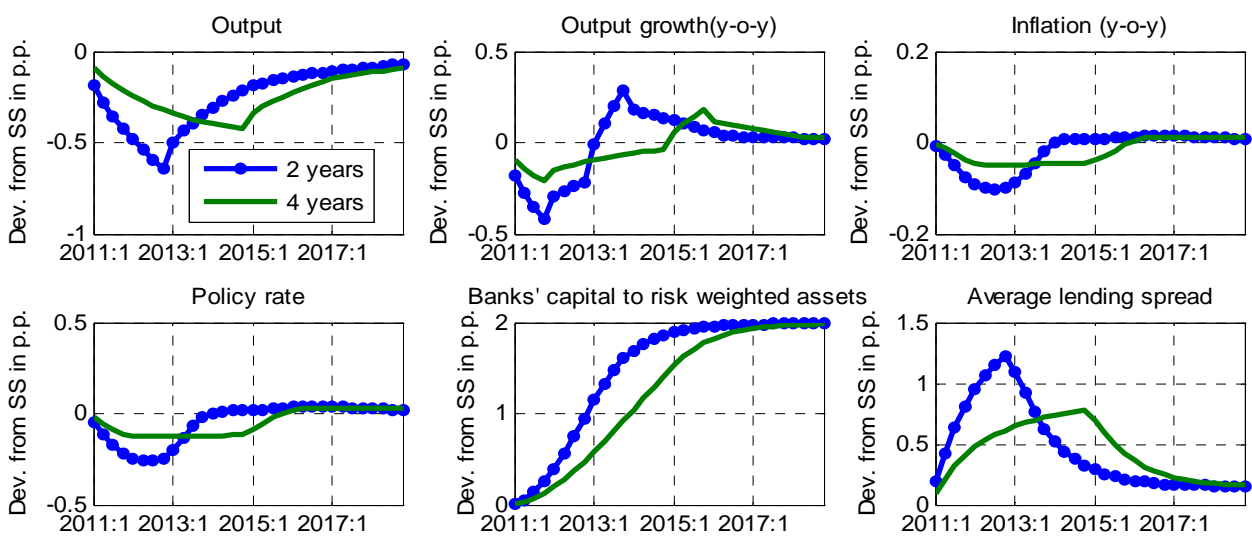

Banks' capital to risk weighted assets
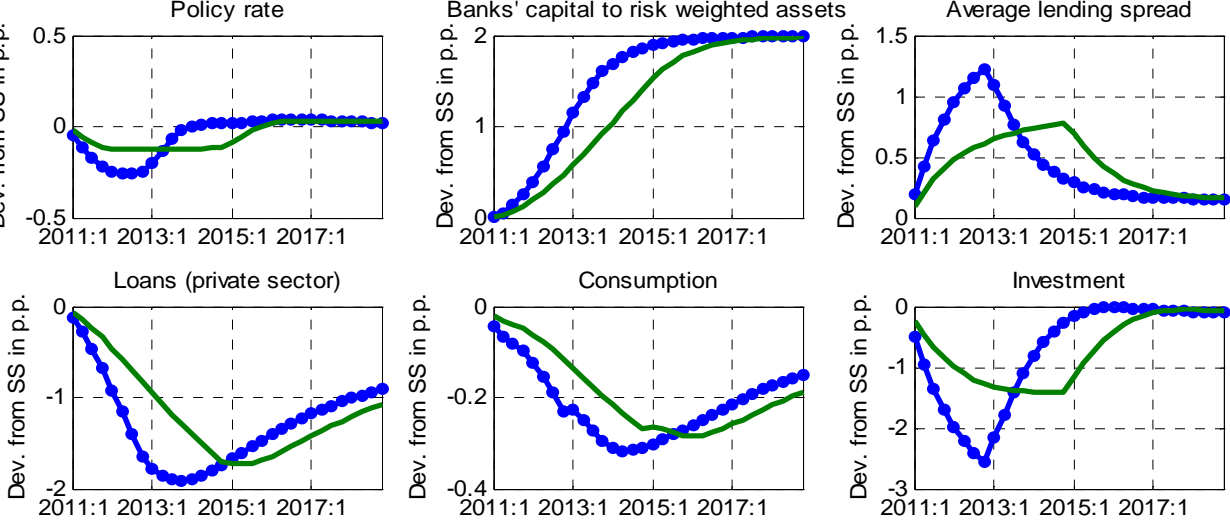

Source: Authors' calculations.

Figure 12. The United States- Effects of Tighter Capital Requirements over Different Horizons

(2 p.p. Increase in Capital Requirements, Increasing Lending Margins)
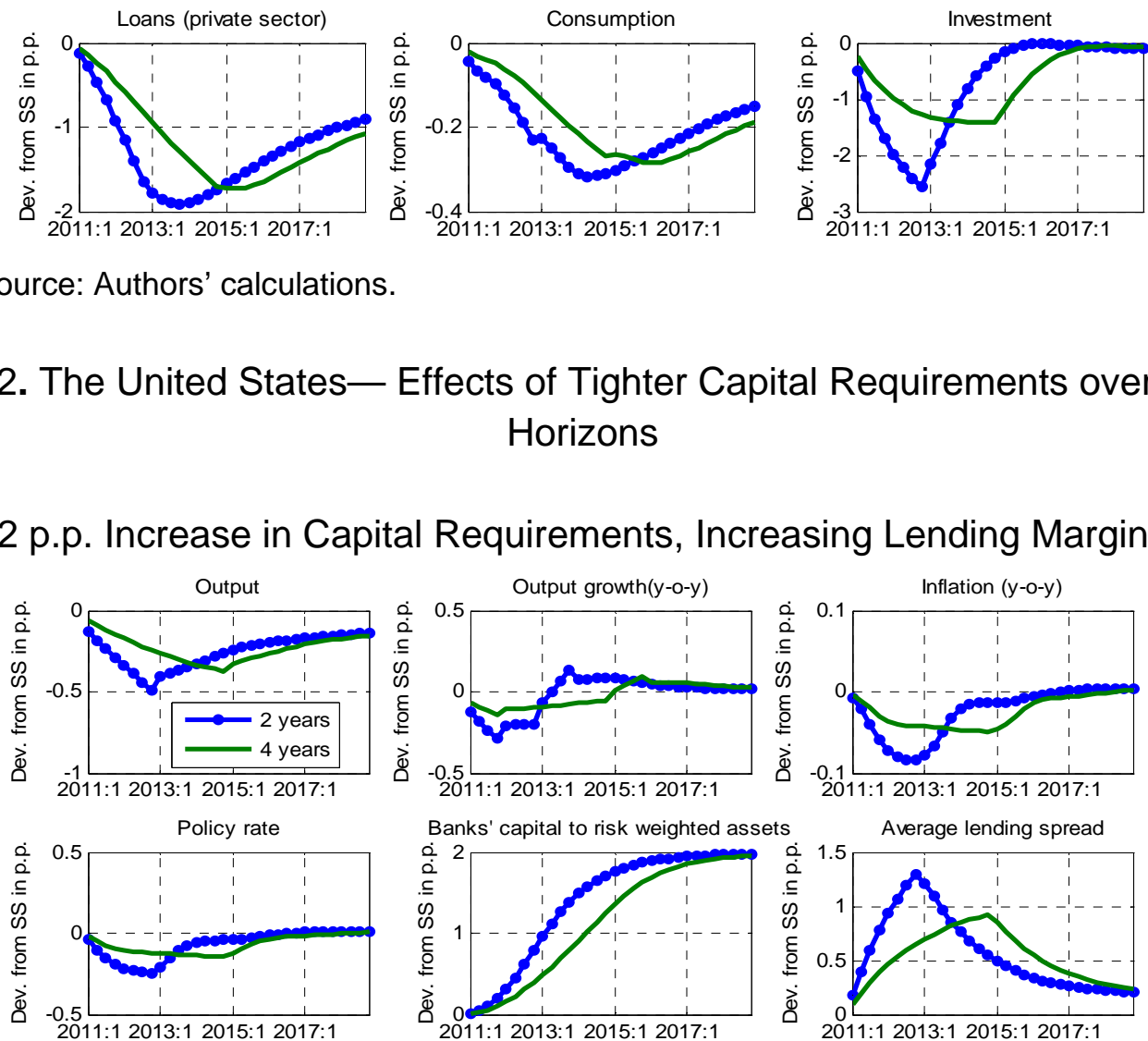

Figure 12. The United States_Effects of Tighter Capital Requirements over Different
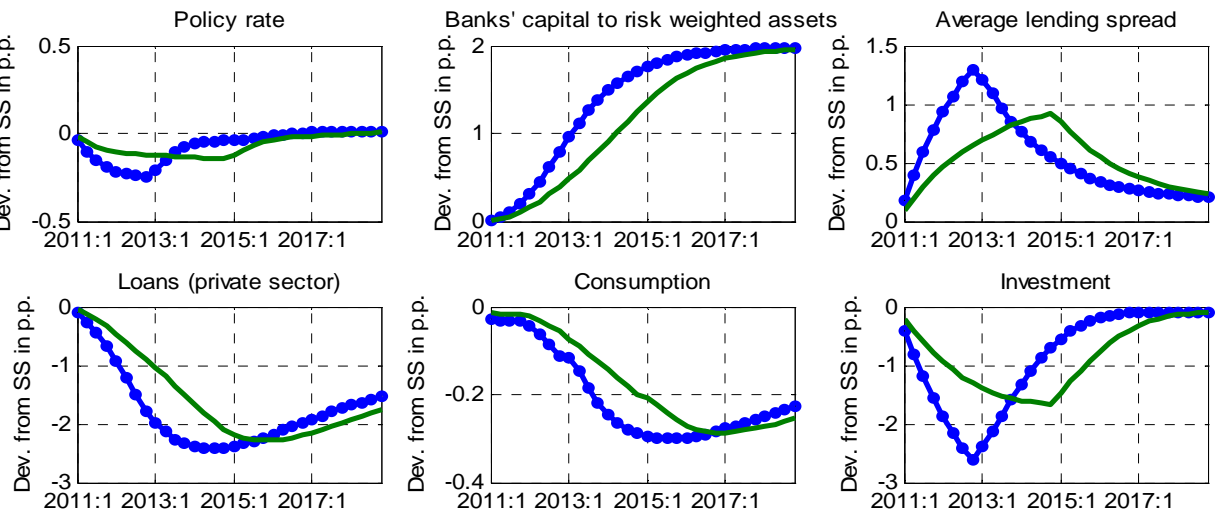

Source: Authors' calculations. 
Figure 13. The Euro Area-Effects of Tighter Liquidity Requirements over Different Horizons

(25 p.p. Increase in Liquidity Requirements with Change of Asset Riskiness)
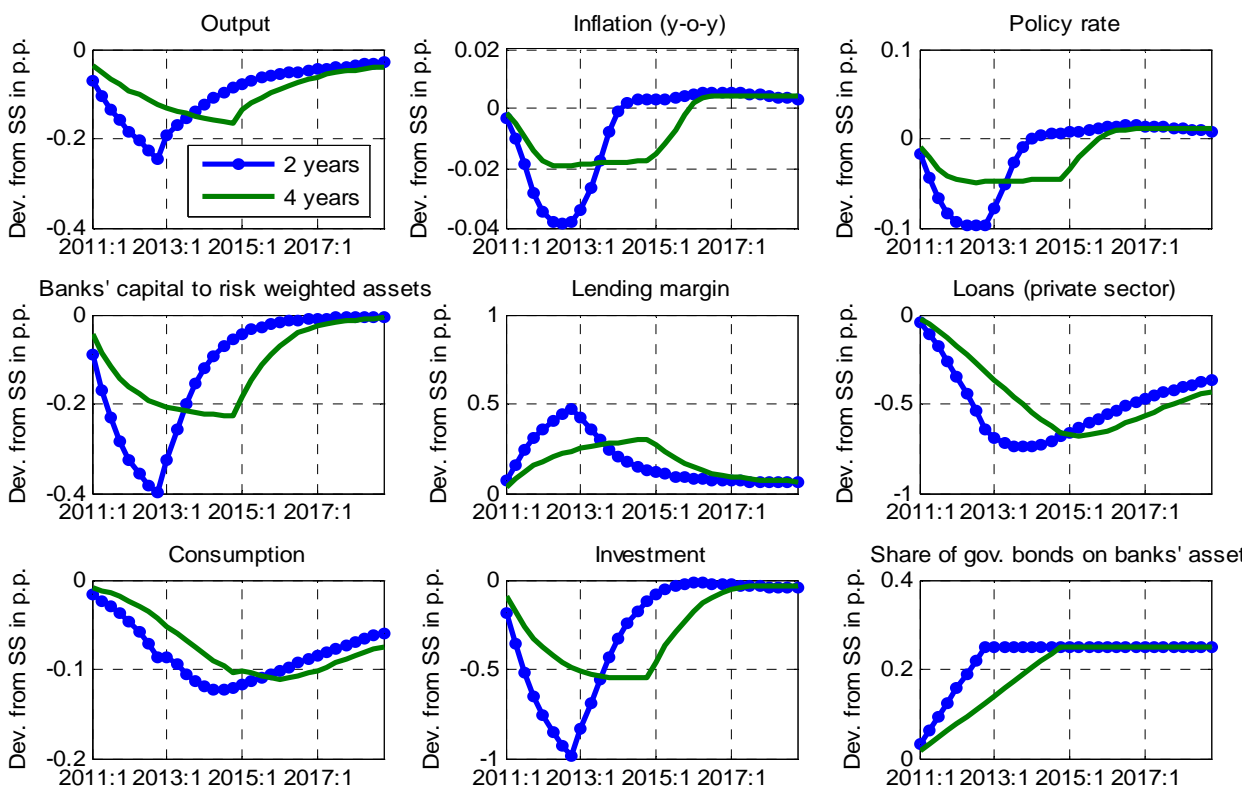

Source: Authors' calculations.

Figure 14. The United States- Effects of Tighter Liquidity Requirements over Different Horizons

(25 p.p. Increase in Liquidity Requirements with Change of Asset Riskiness)
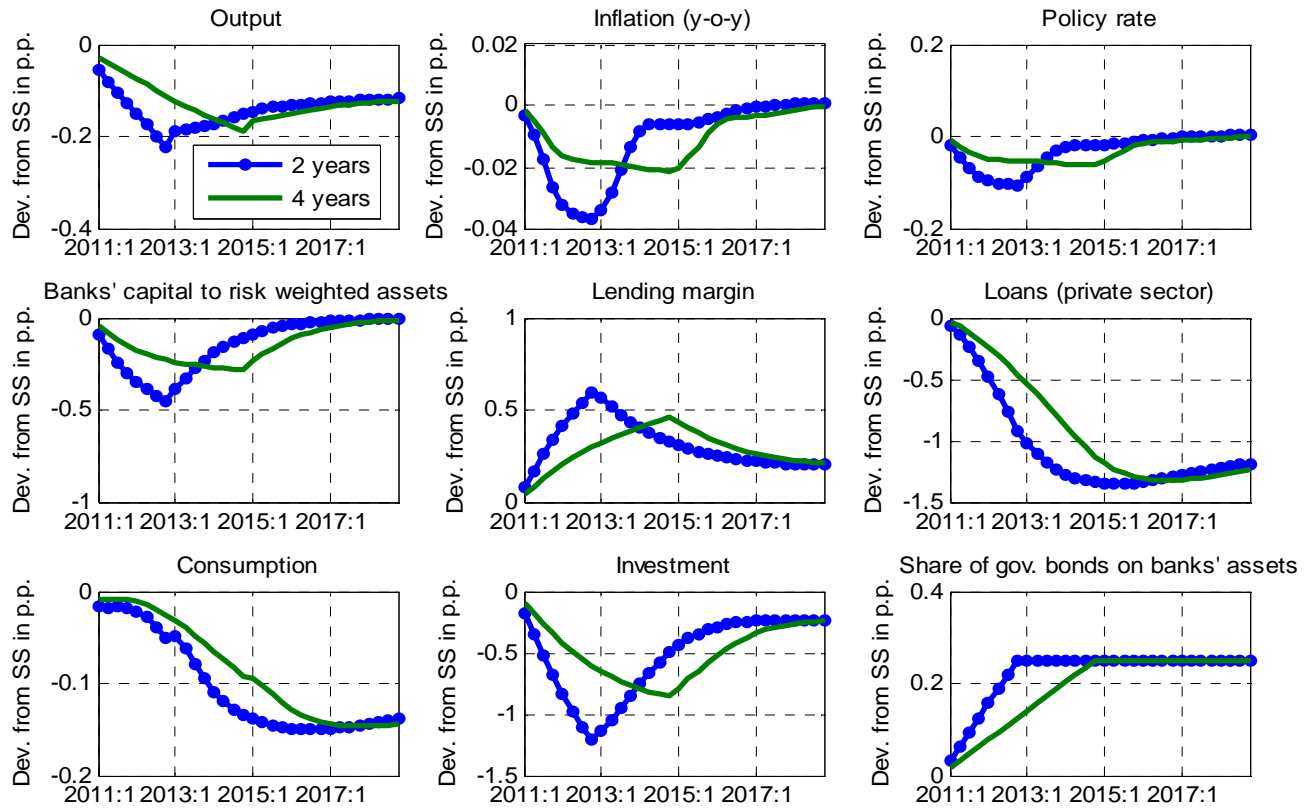

Source: Authors' calculations. 
Figure 15. The Euro Area-Effects of Tighter Capital Requirements under Alternative Monetary Policy

(2 p.p. Increase in Capital Requirements over 2 Years, Increasing Lending Margins)
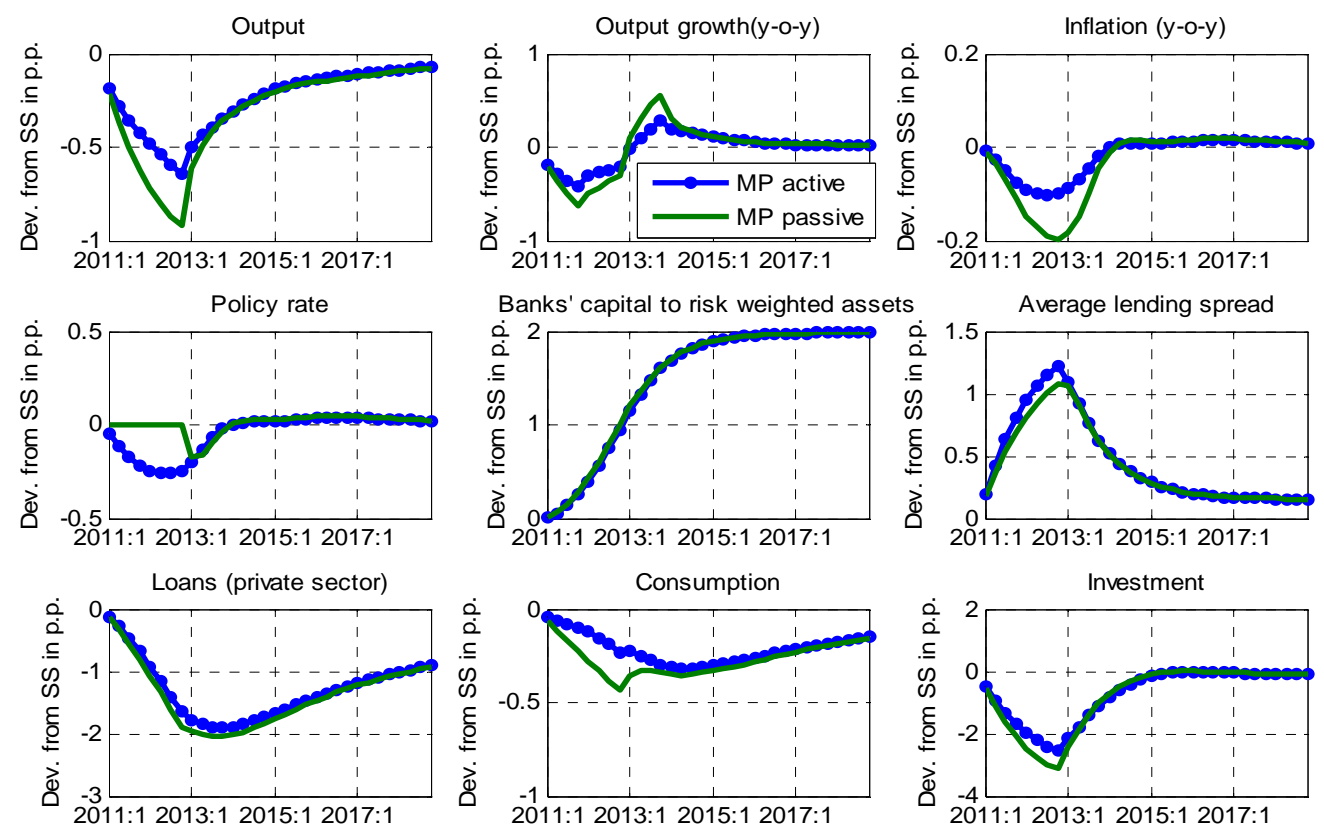

Source: Authors' calculations.

Figure 16. The United States-Effects of Tighter Capital Requirements under Alternative Monetary Policy

(2 p.p. Increase in Capital Requirements over 2 Years, Increasing Lending Margins)
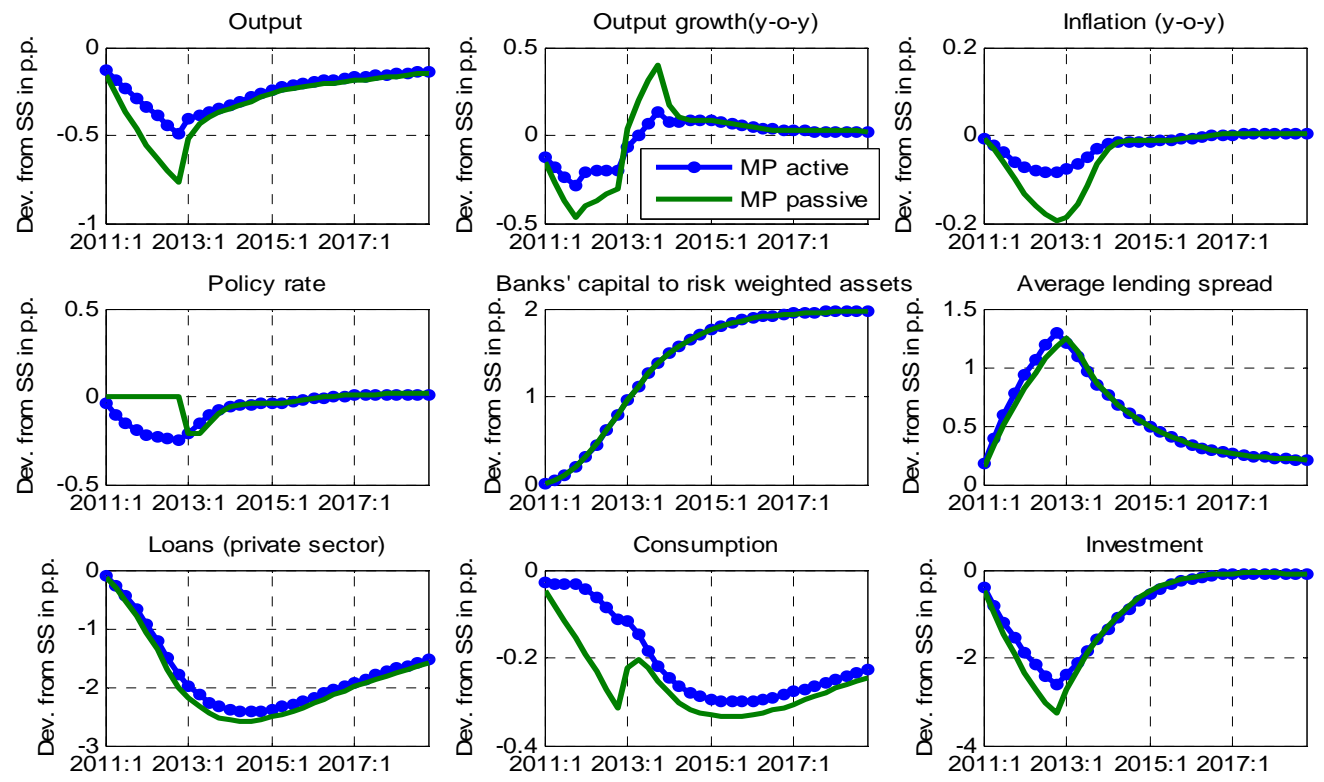

Source: Authors' calculations. 
Figure 17. The Euro Area-Adjustment of the Capital Adequacy Ratio to 1 p.p. Increase of Requirements

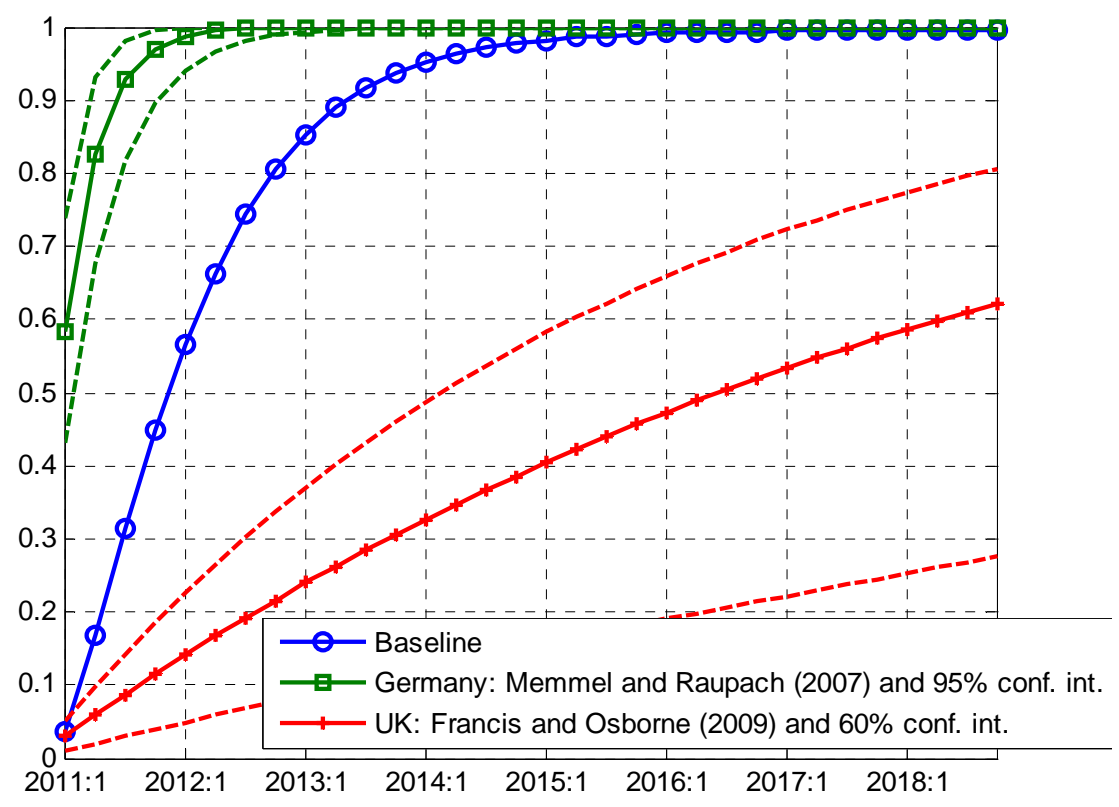

Source: Authors' calculations.

Figure 18. The United States- Adjustment of the Capital Adequacy Ratio to 1 p.p. Increase of Requirements

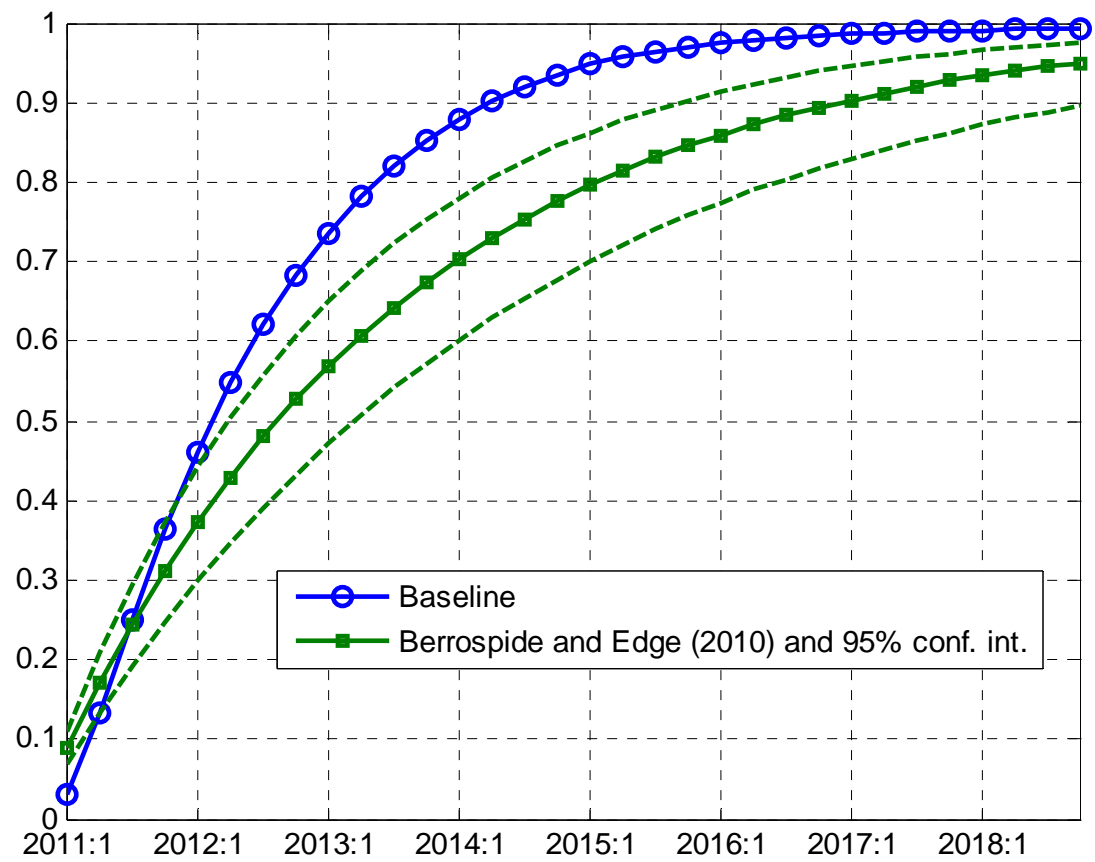

Source: Authors' calculations. 
Figure 19. The Euro Area-Effects of the Penalty Parameter

(2 p.p. Increase in Capital Requirements Over 2 Years)
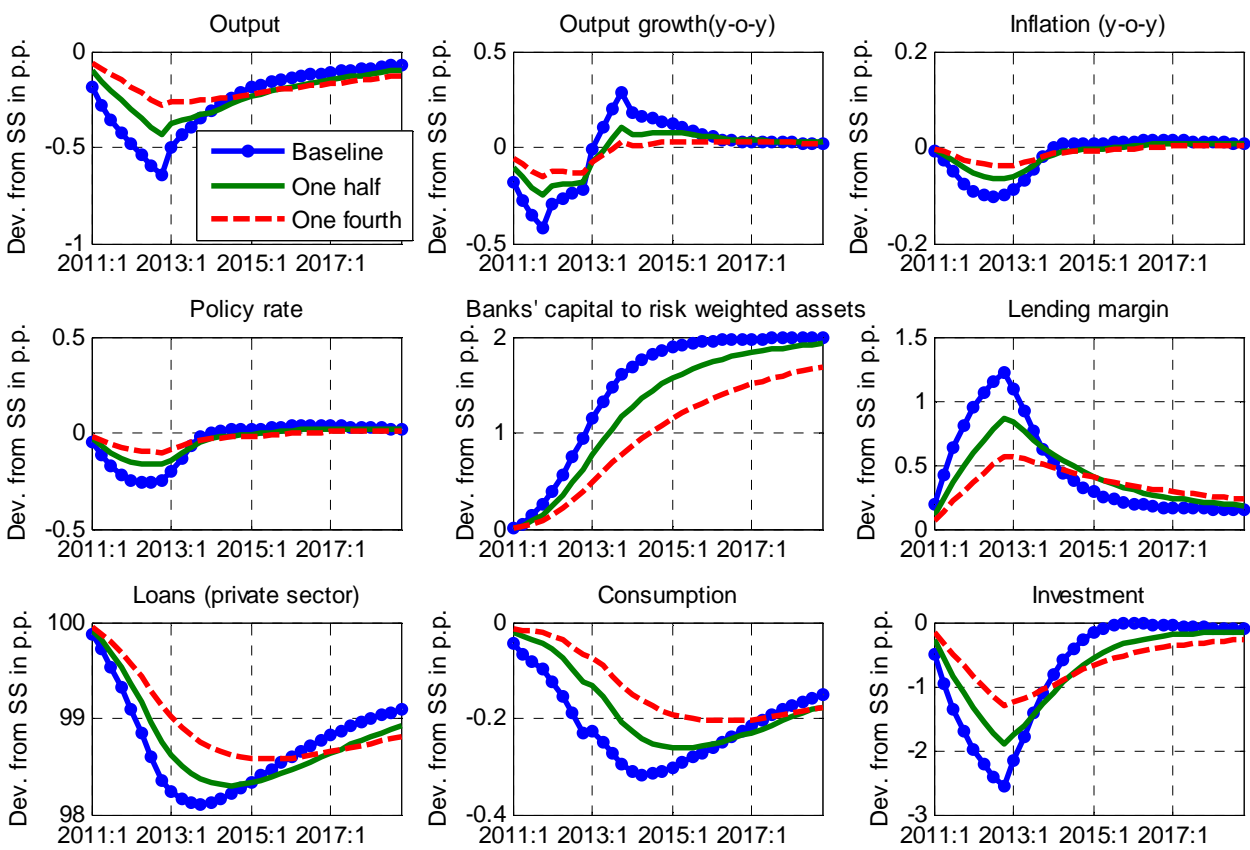

Source: Authors' calculations.

Figure 20. The United States- Effects of the Penalty Parameter

(2 p.p. Increase in Capital Requirements Over 2 Years)
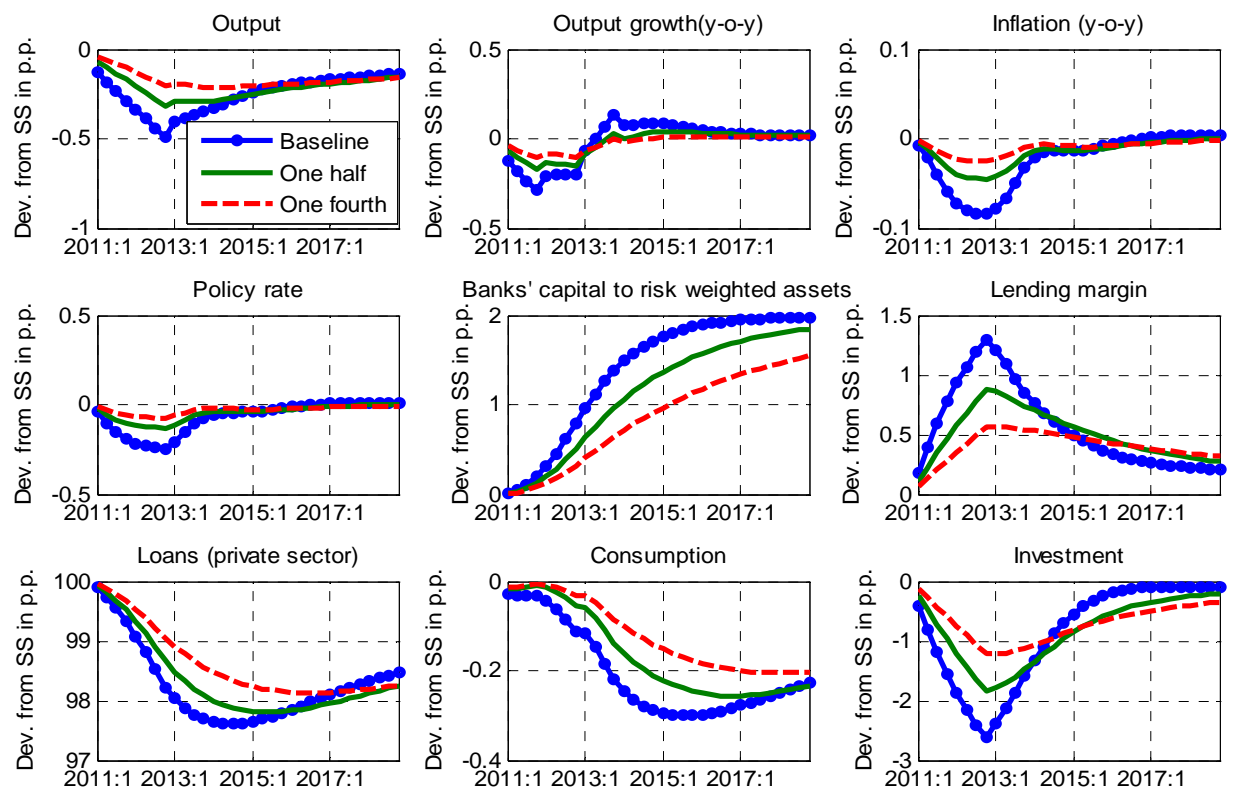

Source: Authors' calculations. 